FEDERAL RESERVE BANK OF SAN FRANCISCO

WORKING PAPER SERIES

\title{
The Pre-Great Recession Slowdown in Productivity
}

\author{
Gilbert Cette \\ Banque de France \\ John G. Fernald \\ Federal Reserve Bank of San Francisco \\ Benoit Mojon \\ Banque de France
}

April 2016

Working Paper 2016-08

http://www.frbsf.org/economic-research/publications/working-papers/wp2016-08.pdf

\section{Suggested citation:}

Cette, Gilbert, John G. Fernald, Benoit Mojon. 2016. "The Pre-Great Recession Slowdown in Productivity.” Federal Reserve Bank of San Francisco Working Paper 2016-08. http://www.frbsf.org/economic-research/publications/working-papers/wp2016-08.pdf

The views in this paper are solely the responsibility of the authors and should not be interpreted as reflecting the views of the Federal Reserve Bank of San Francisco or the Board of Governors of the Federal Reserve System. 


\title{
The Pre-Great Recession Slowdown in Productivity*
}

\author{
Gilbert Cette \\ Banque de France \\ John Fernald \\ Federal Reserve Bank of San Francisco \\ Benoît Mojon \\ Banque de France
}

March 28, 2015

\begin{abstract}
In the years since the Great Recession, many observers have highlighted the slow pace of productivity growth around the world. For the United States and Europe, we highlight that this slow pace began prior to the Great Recession. The timing thus suggests that it is important to consider factors other than just the deep crisis itself or policy changes since the crisis. For the United States, at the frontier of knowledge, there was a burst of innovation and reallocation related to the production and use of information technology in the second half of the 1990s and the early 2000s. That burst ran its course prior to the Great Recession. Continental European economies were falling back relative to that frontier at varying rates since the mid-1990s. We provide VAR and panel-data evidence that changes in real interest rates have influenced productivity dynamics in this period. In particular, the sharp decline in real interest rates that took place in Italy and Spain seem to have triggered unfavorable resource reallocations that were large enough to reduce the level of total factor productivity, consistent with recent theories and firm-level evidence.
\end{abstract}

Keywords: Productivity Growth; Great Recession; Misallocation; Convergence JEL Codes: D24, E23, E44, F45, O47

Please address correspondence to fernaldjg@gmail.com. We thank Fabio Canova, Robert Inklaar, Robert Kolmann, Eric Leeper, Werner Roeger, and seminar participants at several institutions for helpful comments. We also thank Genevieve Denoeux, Andrew Tai and Bing Wang for helpful research assistance. John Fernald thanks the Einaudi Institute for Economics and Finance for hosting him while writing much of the paper. The views in this paper are those of the authors and do not necessarily reflect the views of the Federal Reserve Bank of San Francisco, the Banque de France, or anyone else associated with those institutions. 
Since the Great Recession began in 2007, productivity growth in advanced economies has continually surprised to the downside. ${ }^{1}$ A severe downturn and slow recovery could affect productivity through various channels, both cyclical and structural. But, as we emphasize, the slowdown in advanced-economy total factor productivity (TFP) growth was broadly underway prior to the crisis. ${ }^{2}$ The pre-Great Recession timing suggests the importance of factors other than just the deep crisis (or ensuing policy changes) itself.

To understand the evolution of advanced-economy TFP growth prior to the crisis, we highlight three broad factors that have shaped the global economy in recent decades: Technical change, structural rigidities, and declining real interest rates and abundant credit. Each factor has attracted analysis and attention but they have not, typically, been considered together. For expositional clarity as well as data availability, we focus on a small number of major advanced economies: the U.S. and the four main Euro Area countries (Germany, France, Italy, and Spain). For the United States, which we assume is at the frontier of knowledge, we highlight the temporary burst of innovation and reallocation related to the production and use of information and communications technology (ICT) in the late 1990s and early 2000s. That burst ran its course prior to the Great Recession and forms the backdrop for continental Europe. There, we emphasize changes in the distance to the frontier that started in the mid-1990s: (i) Favorable resource reallocations that did not happen because of structural rigidities in labor- and product markets (France, Germany, Italy and Spain); and (ii) also the unfavorable reallocations—rising misallocation—-that did happen in response to sharp falls in the cost of funding (Italy and Spain).

\footnotetext{
${ }^{1}$ See, for example, Tett (2015).
}

${ }^{2}$ Other studies emphasizing the pre-crisis slowdown in advanced economies include OECD (2015), IMF (2015), Bergeaud, Cette, and Lecat (2014) and Crafts and O’Rourke (2013). For the United States, Fernald (2014) and Byrne, Oliner and Sichel (2013) contain references. An early analysis is by Jorgenson, Ho and Stiroh (2008). 
For southern Europe, we provide some new macro evidence in favor of theories that low real interest contributed to rising misallocation and low productivity growth.

Figure 1 motivates our perspective. The figure shows levels of TFP for major economies. ${ }^{3}$ Post-war convergence in TFP levels stopped in the early 1980s in the U.K., France and Italy and at the end of the same decade in Germany, Spain and Japan. ${ }^{4}$ By 1995, advanced European economies were essentially equal to the U.S. level of TFP, though Spain remained somewhat behind. ${ }^{5}$ Japan was even further behind the frontier.

Between 1995 and 2007, however, countries stop moving together. The U.K. not only keeps pace with the U.S., it pulls ahead somewhat. France and Germany drift down relative to the frontier. But TFP growth in Italy, Spain and Japan plunge relative to the frontier.

To understand these trends, we first discuss the pre-GFC slowdown in productivity growth at the frontier, which we take to be the United States. Labor and total factor productivity (TFP) growth had a resurgence in the second half of the 1990s and early 2000s. But productivity growth slowed markedly prior to the GFC. We update estimates from Fernald (2014), who links this rise and fall to the production and use of information and communications technology (ICT). A large literature argues that ICT can have a broad-based and pervasive effect through its role as a general purpose technology (GPT) that fosters complementary innovations, such as business reorganization. But the transformative nature of these reorganizations is, plausibly, limited. For

\footnotetext{
${ }^{3}$ The data are from Bergeaud, Cette and Lecat (2014). Levels comparisons are fraught with peril, for TFP even more than for GDP; see, for example, Inklaar and Rao (2014) and Inklaar (2015). For this reason, small differences should not be overinterpreted. Nevertheless, the patterns in Figure 1 look relatively consistent across datasets (such as the ones from OECD, Penn World Tables and the Conference Board) and accord with conventional wisdom regarding comparative relative levels and growth rates.

${ }^{4}$ See van Ark, O'Mahony and Timmer (2008) for an overview comparing post-war productivity trends between the United States and Europe.

${ }^{5}$ It does not necessarily follow that these advanced European countries were, at that moment, structurally performing as well as the U.S. For example, several empirical studies find diminishing returns to hours worked and to the employment rate (see Bourlès and Cette, 2007, for a survey and estimates). These countries typically had lower levels of hours per worker or the employment rate than the U.S., which could thus make labor productivity and TFP performance of these countries look relatively strong. For example, lower-skilled potential workers might be employed in the U.S. but out-of-the-labor-force in other countries.
} 
example, once retailing was reorganized to take advantage of faster information processing, the gains may have become more incremental.

Second, for France, Germany Italy and Spain, we highlight how labor and product market regulations made these favorable ICT-related reallocations more difficult. This view, which has arguably been the conventional wisdom since at least the mid-2000s, reflects reallocations that never happened, especially in market services such as distribution and transportation. ${ }^{6}$ In other words, the relative weakness in European productivity growth reflected the interaction of withincountry institutions and changes in global technology.

Third, for peripheral European economies such as Italy and Spain, the reallocations that did occur reduced productivity. Since at least the introduction of the euro in 1999, TFP growth in Italy, Spain, and Portugal has been about zero or even negative. ${ }^{7}$ In the context of Italy, Hassan and Ottaviano (2013) describe this as “the great unlearning” of negative TFP growth. A number of studies (cited in Section 3) find that the allocation of resources worsened in southern Europe but not in other advanced economies. Other things equal, this reduced TFP growth because the average efficiency of production got worse.

Why did misallocation rise in southern Europe? A recent strand of literature (e.g., Reis, 2013, Gopinath et al., 2015, and Gorton-Ordonez, 2015) argues that low real interest rates and abundant credit led to misallocation and weak productivity growth. For example, in Reis’s (2013) model, capital inflows into a country that has inefficient financial intermediation not only reduces real interest rates but induces a shift towards lower quality entrepreneurs. Lower interest rates encourage more entrepreneurs to seek to create firms. At the margin, banks are willing to

${ }^{6}$ See Inklaar (2015), Bourlès, Cette, Lopez, Mairesse, and Nicoletti (2013), Cette, Lopez, and Mairesse (2013), and van Reenen et al. (2010) for references and discussion.

${ }^{7}$ We do not focus on Portugal in this paper because of its smaller size and lack of industry TFP data for our later analysis. 
fund those firms rather than more productive ones because of a financial friction: Because of information asymmetries, banks allocate funds in part as a function of collateral. Collateral constraints, in turn, cap the borrowing capacity of even the most productive entrepreneurs. As a result, when interest rates fall, banks end up financing investments by less efficient firms. In other words, capital inflows that push interest rates down reduces the average productivity in the economy by lowering the bar for less productive entrepreneurs.

This mechanism can be compounded by a boom in consumption, where tradables are imported and non-tradables are produced by small and inefficient local firms. Kalantzis (2014) shows that the share of non-tradables in domestic output typically increases following episodes of capital inflows (see also Benigno et al., 2015). Nevertheless, this shift towards non-tradeables is probably not the entire story. As Gopinath et al. (2015), for example, show for Italy, Spain and Portugal, misallocation has increased within manufacturing since the launch the euro.

Finally, Challe et al. (2015) describe a third mechanism whereby low interest and "soft budget constraints" reduce the incentives to maintain good governmental institutions such as rule of law. That, in turn, reduces average productivity.

The most novel part of this paper is to provide new evidence that is consistent with a link between lower real interest rates and weaker productivity growth. In particular, we test the implication of the models described above that negative shocks to long-term interest rates should reduce productivity growth. Evidence, either from identified vector autoregressions (VARs) or from fixed-effect regressions on a panel of 18 industries for 13 OECD countries, provide some support for this conjecture. Given that real interest rates fell the most in Southern Europe, the effect of low real rates on productivity was larger in Spain and in Italy than in Germany, France, the U.K. or the U.S. These results are consistent with the estimates of Borio et al. (2015)—with 
different data, fewer sectors, and a larger cross section of countries-which finds that fast credit growth leads to lower productivity growth.

To summarize, in the run-up to the crisis, trends in advanced-economy productivity involved a slowdown at the frontier and important interactions between country-specific institutions and the shocks that hit the global economy. The four main euro-area countries were not able to take full advantage of opportunities for productivity-enhancing reallocations and Spain and Italy were not able to take full advantage of declining real interest rates.

We do not address the U.K. in detail, but it seems a specific case. As Figure 1 shows, the U.K. exceeded U.S. TFP performance from the mid-1990s to 2007. But a sharp break came with the crisis, and relative TFP declined. For some continental economies, low factor utilization may still play a role in obscuring productivity trends; indeed, as of mid-2015, the OECD estimates that output gaps remain very large. But for the U.K., resource slack had sharply diminished well before this writing. Barnett et al. (2014) and Haskel et al. (2015) discuss a range of alternative explanations but conclude that much remains unexplained.

Many of the arguments here are not new. For example, Fernald (2014) discusses the U.S. experience. Van Ark, O’Mahony and Timmer (2008), van Reenen et al. (2010), Bourlès et al. (2013) and Cette, Lopez and Mairesse (2014) discuss the role of labor and product market rigidities. Reis (2013), Gopinath et al. (2015), Kalantzis (2014) and Challe et al. (2015) discuss southern Europe. Gorton and Ordonez (2013), Cecchetti and Kharroubi (2015) and Borio et al. (2015) discuss the effects of credit booms on productivity. Our innovation is to bring together, update, and augment these sometimes disparate arguments into a single broad narrative for advanced economies. In addition, we provide new evidence on how interest rate changes may influence productivity. 
The outline of the paper is as follows. Section 1 discusses facts about convergence and divergence. Section 2 discusses the ICT-related rise and fall of productivity growth in the United States and the role of labor- and product-market rigidities in Europe. Section 3 discusses the role of rising misallocation in southern Europe, along with new econometric evidence. Section 4 concludes with a discussion of implications of these pre-recession findings for understanding trends since 2007.

\section{Facts: Productivity Convergence and Divergence}

This section discusses key stylized facts about post-war productivity growth—namely, the convergence and divergence in productivity levels that took place prior to the Great Recession. (See also previous analyses in, for example Bergeaud et al., 2014, or Crafts and O’Rourke, 2013.) As noted earlier, Figure 1 shows the level of TFP relative to the U.S. since 1950 for selected advanced economies: The U.K., the four largest euro-area countries (Germany, France, Italy and Spain) and Japan. Figure 2 gives the same representation for relative levels of labor productivity (GDP per hour worked).

These figures show that a conditional-convergence perspective describes the country experience reasonably well until the mid-1990s. Countries grew fast and caught up towards U.S. levels until roughly the end of the 1980s. GDP per hour appears to converge slightly slower than TFP (van Ark et al., 2008, also make this point). By 1995, France, Germany, and even Italy are above U.S. levels in these data.

In conditional convergence models, each country may have its own steady-state level relative to the frontier. But a natural benchmark expectation is that, once convergence ends, countries grow at the frontier rate even if they are at different levels of productivity. Ideas spill across borders, however imperfectly and perhaps with lags. Innovations in one country are, in 
principle, available in all countries. In some cases, innovations can be directly observed and (perhaps with some effort) replicated. In other cases, key innovations are embedded in tangible or intangible goods that can be purchased, such as information technology hardware and software. And cross-border investments further transfer knowledge. But of course, there might be institutional barriers that interfere and keep countries from reaching the frontier level.

In contrast to this expectation of stable relative levels, however, countries other than the U.K. decline relative to the U.S. after the mid-1990s. For continental Europe, the experience after 2008 largely continues the pre-Great Recession trends. Even Japan, though further away from frontier level of TFP and labor productivity, evolves similarly.

The bar chart in Figure 3 shows further growth-accounting detail on the main components of labor productivity growth, including TFP, for the same set of countries (excluding Japan) over various sub-periods from 1974. Consistent with convergence, growth in labor and total factor productivity slowed in most countries (other than the U.S. and U.K.) after the mid-1990s. More interesting for our purposes are the sources of the subsequent crosscountry divergence. Broadly, it reflected both TFP and ICT-related capital deepening. After the mid-1990s, the U.S. saw markedly faster growth in both of these components. In contrast, outside the U.S. and U.K., countries showed slower TFP growth and the same or slower ICTrelated capital deepening. Given the ICT story we emphasize in the next section, it is worth noting that the U.S. and the U.K. benefited more than continental Europe from ICT capital deepening across all sub-periods.

In sum, after 2004—but prior to the Great Recession—U.S. TFP growth and ICT-related capital deepening both slow. Fernald (2014) reports that formal break tests show a statistically significant speedup in the mid-1990s and slowdown in the early- to mid-2000s (exact break dates 
depend on which series is used, and range from 2003 to 2006.) In all cases, the 2000s break dates are prior to the Great Recession, and confidence intervals typically exclude that event.

Outside the U.S., the important slowdown occurred a decade earlier, with the end of convergence and beginning of divergence. Since 1995, TFP growth is particularly low and close to zero in Italy and in Spain. ${ }^{8}$

The conditional convergence perspective shapes our subsequent argument. We focus first on the frontier of knowledge and productivity, which we take to be the United States. Second, we look at what was happening away from the frontier. Shocks of different sorts-whether to the nature of technology (such as the ICT revolution) or to capital flows-may interact in particular ways with country-specific institutions to push countries closer to or farther from the frontier. After the mid-1990s, the four European continental countries have lower ICT diffusion and productivity gains than the U.S. One aspect is more stringent regulations of labor and product markets, as a large literature has noted. But the TFP collapse in Italy and Spain could also be linked to disparate roles of reallocation and misallocation. Section 2 discusses these aspects and Section 3 discusses the role of capital flows and low real interest rates in the periphery.

\section{Industry origins of the pre-Great-Recession productivity slowdown}

To gain further insight into the nature of the pre-Great-Recession slowdown, we turn to industry data. For the United States, which we take to be at the frontier of knowledge, ICT investment and associated business reorganization plausibly explain the rise and fall of productivity growth since the mid-1990s. ${ }^{9}$ For France and Germany, the lack of these

${ }^{8}$ German productivity grew strongly in 2004-2007, in part reflecting the strength of the business cycle. As Figure 1 showed, the temporary recovery in German TFP growth was insufficient to reverse the trend decline relative to the U.S.

${ }^{9}$ Taking the U.S. as the frontier is conventional. The OECD (2015), which focuses on diffusion and misallocation, takes a different perspective and analyzes the "global frontier" of firms in detailed industries. Nevertheless, OECD (2015) and Andrews et al. (2015, p.15) find relatively little evidence of misallocation for the 
reorganizations appears to play an important role. For Italy and Spain, we discuss the hypothesis that the problem was growing misallocation.

\subsection{U.S. experience: An easing in the ICT revolution?}

A plausible hypothesis for the United States, at the frontier, is that the pace of technological change associated with information and communications technology slowed.

Faster TFP growth in producing ICT products can, conceptually, raise aggregate TFP and labor productivity growth through several channels (see, for example, Basu, et al., 2003). Most directly, it raises aggregate TFP growth by raising it in the industries that produce ICT products. The resulting decline in the relative price of investment goods then affects capital deepening by ICT-using sectors. In a neoclassical framework, this raises labor productivity growth, but not TFP growth, in those sectors.

However, non-ICT-producing U.S. industries also showed faster TFP growth in the late 1990s or early 2000s (e.g., Basu et al., 2003, and Bosworth and Triplett, 2006). An important channel through which declining ICT prices can affect measured TFP is by fostering complementary innovations, such as business reorganization, to take advantage of an improved ability to manage information and communications. ${ }^{10}$

In retailing, for example, ICT led firms to innovate in how they manage sales, inventories, and supply chains; the Internet is an extreme example, in that it has made possible completely new ways of doing business. In addition, reallocation towards higher-productivity establishments amplified the effects, as new or existing firms that were particularly adept at using new technologies (and thus more productive) grew, while less capable establishments

U.S. Although U.S. firms are not necessarily at the "global frontier" of knowledge, the distribution of firm size is more allocatively efficient, in that more productive firms are larger. See also Bartelsman (2013).

${ }^{10}$ Van Reenen et al. (2010) review the evidence on complementary intangible investments with a focus on firm-level evidence. Earlier examples include Brynjolfsson and Hitt (2000). 
exited. ${ }^{11}$ In valve manufacturing, Bartel, Ichniowski, and Shaw (2007) find that ICT led to a change in business strategies to focus on product customization rather than large commodity runs. Implementing this change required changes in worker skills as well as in management and human-resource practices. More broadly, Brynjolfsson and Hitt (2000) and others highlight the lags associated with complementary managerial and organizational innovations. ${ }^{12}$

For a wide swath of the economy, improved ability to manage information and communications has certainly led to changes in how firms do business. But it was unclear $a$ priori how long the transformative and explosive opportunities would last.

Figure 4 illustrates how these dynamics have played out in U.S. industry data, which will then foster comparison across countries. The figure uses BLS industry data on U.S. TFP; these data run from 1987-2013 (see the data appendix). The height of the bars shows TFP growth for the time-periods shown. Cyclical factors from the Great Recession are probably not important in U.S. data by 2013. Nevertheless, given our pre-recession focus, we concentrate on the period through 2007. Our main conclusions are robust to considering the entire 2004-2013 period. ${ }^{13}$

There were "unusual” features of the mid-2000s—with the housing boom and subsequent bust; excesses in the financial sector; and surging commodity prices. To see if these factors affected productivity, one data slice focuses on the "bubble" sectors of construction, real estate, finance, and natural resource industries. The contribution of these industries to overall TFP fell_-becoming negative-from 2000-2004 to 2004-2007. But the contribution of the remaining $3 / 4$ of the economy also fell sharply.

\footnotetext{
${ }^{11}$ See Doms (2004) and Foster, Haltiwanger, and Krizan (2006). Fernald and Ramnath (2003) provide a brief case study of how Walmart used ICT to raise productivity.

${ }^{12}$ A large literature views ICT as a "general purpose technology." See, for example, Greenwood and Yorokoglu (1997), Brynjolfsson and Hitt (2000), Basu et al. (2003), and Brynjolfsson and McAfee (2014). Basu et al. (2003) discuss some of the nuances of interpreting productivity movements in such a setting. In their model, there is unmeasured investment in reorganization, and an unmeasured service flow from the resulting intangible organizational capital. Van Reenen et al. (2010) report evidence for ICT-linked-intangibles in micro data.

${ }^{13}$ Fernald (2014) argues that cyclical factors were not important drivers of productivity from 2004-2007.
} 
These non-bubble sectors are divided into three mutually-exclusive pieces: ICT producing, market services, and everything else (the residual). The contribution of ICT producers was inordinately high in the late 1990s, accounting for over half of overall TFP growth in this period-even though they account for only 6 percent of the economy. Much of that surge reflected gains in hardware production, in part because competition within the semiconductor industry led to the faster introduction of new chips. In the 2000s, the pace of TFP gains in ICT production eased and its share in GDP declined (see Byrne, Fernald, and Reinsdorf, 2016). Hence, the direct contribution of ICT-producing industries fell.

In the early 2000s, the contribution of market services industries especially bulged. We define this group as wholesale and retail trade, transportation, information, and business services. ${ }^{14}$ After 2004, the TFP contribution fell most sharply in that market services group. These industries are also much more ICT-intensive than the residual “other” group.

That pattern is consistent with the view that benefiting from ICT requires substantial intangible organizational investments that, with a lag, raise measured productivity. By the mid2000s, the "low-hanging fruit" of ICT-based innovation had been plucked. ${ }^{15}$ For example, industries like retailing may have already have been substantially reorganized, after which the gains from further innovation have been more incremental.

Of course, the residual “other” group also shows a slowdown after 2004. This group includes manufacturing (other than ICT producing and petroleum refining), utilities, and some services. Thus, although the (ICT-intensive) market services show the greatest slowdown, it is also accurate to say that the slowdown in TFP growth is relatively broad-based across industries. After 2007, TFP growth was maintained mainly by the bubble sectors.

\footnotetext{
${ }^{14}$ We exclude ICT-producing software publishers. Most studies would also include finance, which is in the bubble sector.

${ }^{15}$ See also Gordon (2014) and Cowen (2011).
} 


\subsection{Labor-and product-market rigidities in Europe}

Figure 5 shows the corresponding industry patterns of TFP growth for the major European economies - Germany and France in the top row, and Italy and Spain in the bottom row. These data are from the EU-KLEMS database and end in 2010. These figures provide insight into why Continental Europe didn’t get the same mid-1990s acceleration as the United States. They also provide key stylized facts for the VAR analysis in the next section. The final bar (2007-2010) is heavily affected by the Great Recession. So, once again, we focus on the earlier periods.

The pre-Great-Recession bars show strikingly different patterns from the U.S. figures. First, unlike the U.S., ICT production adds relatively little anywhere-particularly Italy and Spain. Second, and more strikingly, European economies never got the substantial boost in TFP growth for ICT-intensive market services in the late 1990s and early 2000s. The market-service contribution is small—sometimes negative and sometimes positive—in Germany and France. It is a sizeable negative throughout in Italy and Spain.

An important caveat is that industry measurement is not always comparable across countries. Of relevance to the market-services differences, Inklaar and Timmer (2008) point out that the U.S. measures the output of distribution services differently from many European economies. However, using comparable methods, Inklaar and Timmer still find that U.S. retailing productivity rose substantially faster than in Germany or France (they do not analyze Italy or Spain). Thus, the differences in methods are probably not important enough quantitatively to change the broad differences shown in the figures. They are an important caveat, of course, since their importance could be changing over time. ${ }^{16}$

\footnotetext{
${ }^{16}$ We thank Robert Inklaar for perceptive observations on the potential growing importance of crosscountry measurement differences.
} 
Taking the differences as real, what explains the relatively poor performance of market services in Europe? Many studies have argued that Continental Europe was unable to benefit as much from reorganizations associated with ICT as the U.S. and U.K.

For example, ICT investment has been higher in the U.S. than in the U.K., and in the U.K. than in continental Europe. (Figure 3 showed how these investment rates translate into differences in direct ICT-related capital deepening.) The lag of ICT diffusion in continental Europe is considerable. ${ }^{17}$ Numerous studies provide explanations, including the level of postsecondary education among the working-age population as well as labor- and product-market rigidities. ${ }^{18}$ For example, an efficient use of ICT requires a higher degree of skilled labor than the use of other technologies. Adopting ICT effectively often requires reorganizing firms, which can be constrained by strict labor-market regulations. Moreover, low levels of competitive pressure, resulting from product-market regulations, can reduce the incentive to exploit the most efficient production techniques. Cette and Lopez (2012) use cross-country panel data and find that the U.S. benefits from the highest level of ICT diffusion because of a higher level of post-secondary education among the working age population and less restrictive product- and labor-market regulations. Using cross-country cross-industry panel data, Cette, Lopez and Mairesse (2013) also show also that market rigidities lower ICT diffusion and R\&D spending.

From a wider perspective, Bourlès et al. (2013) find that product-market regulations in upstream (supplying) industries has significantly held back TFP growth in recent decades. Similarly, Cette, Lopez and Mairesse (2014) find that tighter labor- and product-market regulations in continental Europe have reduced TFP growth relative to the U.S. and U.K.

${ }^{17}$ See Schreyer (2000), Colecchia and Shreyer (2001), Pilat and Lee (2001), van Ark et al. (2008), Timmer et al. (2011), Cette and Lopez (2012), Cette, Clerc and Bresson (2015).

18 See Aghion et al. (2009), Guerrieri et al. (2011) and Cette and Lopez (2012) who use country-level panel data, as well as Cette et al. (2013) who employ sectoral-level panel data. 
Haltiwanger, Scarpetta, and Schweiger (2014) find that strict hiring and firing regulations tend to reduce the pace of job reallocation. Garicano, Lelarge, and Van Reenen (2012) find that steep nonlinearities in French labor costs for firms above 50 employees have major effects on firm size and productivity.

Still, while the pattern for core Europe looks different from that of the United States, TFP growth was, by and large, positive prior to the crisis. In contrast, the bottom row of Figure 5 shows Spain and Italy. TFP growth was negative after the mid-1990s in these data. Market services stand out as a consistently negative contributor from 1995 on in both countries.

Nevertheless, every broad industry grouping contributed negatively in one period or another. ${ }^{19}$

Conventional wisdom suggests that the shift towards housing and real estate was a big drag on TFP growth in Spain; according to EU KLEMS, this is correct, as shown by the negative drag from the "bubble sector" from 2004-07. But it wasn’t just the shift towards housing. Market services (mostly non-traded) contributed substantially negatively, as did the (mostly traded) “other” category in Spain in the late 1990s and in Italy from 1995-2004. In other words, weak or negative TFP growth has been a broad fact across sectors.

Thus, the story for peripheral Europe prior to the crisis needs to apply broadly across the economy—it is not just a matter of the mix of activities. We turn to that region next.

\section{Increasing capital misallocation in peripheral Europe}

This section focuses on the so-called periphery of the euro area, mainly in southern Europe. As already noted, from 1995 to 2007, TFP growth was zero or negative in this region. ${ }^{20}$

${ }^{19}$ These EU-KLEMS figures differ somewhat from the aggregate figures reported earlier but are broadly consistent. The EU-KLEMS data are from earlier vintages of national accounts data, and they exclude non-business (mainly government, health care, and education). They also have an adjustment for labor quality, which reduces measured TFP growth. But the general patterns in the data are unaffected.

${ }^{20}$ In the Cette et al. (2014) data shown in Figure 3, TFP growth was essentially zero in these economies. In OECD data, TFP growth was slightly negative. Conference Board data (https://www.conference- 
Negative TFP growth implies that a given amount of capital and labor produces less output over time. Although TFP is closely related to innovation and learning, negative TFP growth does not necessarily reflect "forgetting." Rather, it could mean that resources are allocated less efficiently across producers over time, thereby reducing the "average efficiency" of the economy. For given capital and labor, an economy's output (and, thus, its level of TFP) is maximized if the value of the marginal products of capital and labor are equalized across all uses. In that case, there is no way to shift resources across producers that would raise overall output. ${ }^{21}$ In contrast, if (the value of) marginal products are not equalized, then shifting resources from lower to higher marginal product uses would reduce misallocation and raise TFP. Conversely, if resources are shifting towards lower marginal product uses, then misallocation can get worse and aggregate TFP could fall.

Empirically, research using establishment or firm-level data on Southern Europe documents substantial and growing misallocation. Gopinath et al. (2015) find that the misallocation of capital (measured by the standard deviation of the value of the marginal product) was steadily rising in Italian and Spanish manufacturing since the late 1990s. Much of this increase occurred prior to the crisis. Similarly, using a different dataset for Italian manufacturing, Calligaris (2015, Figure 3) finds that TFP in 2007 would have been 12 percent higher if the efficiency of resource allocation had remained at its 1997 level. For Spain, GarciaSantana et al. (2015) find that misallocation rose in essentially all sectors of the economy from

board.org/data/economydatabase/index.cfm?id=27762) were even more negative. Indeed, from 2001-2007, TFP growth was negative in Portugal and Ireland as well as in Spain and Italy; TFP growth was zero in Greece. The only other euro-area economy with negative TFP growth over this period was Luxembourg.

${ }^{21}$ Basu and Fernald (2002) and Fernald and Neiman (2011) present growth-accounting decompositions of how resource reallocations affect measured TFP. The growth-accounting approach does not require a complete structural model but also does not easily allow counterfactuals. Hsieh and Klenow (2009) provide a formal structural model of how resources are allocated across producers in the presence of factor- and output-market frictions. With that calibrated model, they can perform counterfactual exercises to assess how much productivity would be increased by eliminating or at least reducing these (static) distortions. 
1995-2007. Rising misallocation, they argue, held down TFP growth by about 1-1/2 percentage points per year.

In contrast, there is little evidence that rising misallocation was an important part of the story in the U.S. or "core Europe.” Bartelsman, Haltiwanger, and Scarpetta (2013) look at the U.S., U.K., Germany, and several other countries (but not Spain or Italy) and find that misallocation remained roughly constant in the 1990s and early 2000s. Similarly, Bellone and Mallen-Pisano (2013) find little change in misallocation in France from 1998 and 2005.

The story for rising misallocation in Southern Europe probably cannot be countryspecific. For example, many authors point to the shift towards housing in Spain in the run up to the crisis, and away from housing after the crisis. But as we already saw in Figure 5, TFP growth was weak in most sectors in Spain. Moreover, Italy, which did not see the same housing boom, saw a similar TFP collapse, in both relative and absolute terms. Pellegrino and Zingales (2014) discuss three hypotheses for Italy: the challenges responding to the ICT revolutionalong the lines emphasized for France and Germany in Section 2; increasing global competition, especially from the rise of China; and the introduction of the euro. ${ }^{22}$ These common "shocks" could interact with country-specific institutional features to generate differential outcomes.

In the remainder of this section, we explore the third hypothesis, that misallocation got worse because of the introduction of the euro. It is, of course, not immediately obvious why the advent of the euro (effectively, a choice of monetary policy regime) should affect medium- and long-run productivity growth. The default in many macro models is that such a choice of monetary regime should be approximately neutral with respect to productivity apart from shortrun business-cycle dynamics.

\footnotetext{
${ }^{22}$ Also in the context of Italy, Hasan and Ottaviano (2013) point to poor management for many firms (such as promoting based on seniority rather than ability) and, relatedly, low diffusion of ICT.
} 
Below, and in the introduction, we discuss recent models that suggest a linkage between the advent of the euro and weak productivity performance. These models assume that the introduction of the euro led to reductions in nominal and real interest rates in peripheral economies. Figure 6 and Figure 7 show that this is the case: interest rates fell much more in Italy and Spain than in France, Germany or the U.K. In nominal terms, Italian and Spanish 10-year government rates fell from around 12 percent in 1995 to around 5 percent when the euro was introduced in 1999. In real terms (Figure 7), German rates were the lowest in Europe in the early to mid-1990s but were the highest in Europe in the early- and mid-2000s. Indeed, because of higher inflation, Spanish real interest rates declined steadily from 1995 to 2005, when they reached -1 percent. (Note that, in the models discussed below, it does not matter whether real rates are low because nominal rates are low or because inflation is high.)

Such drops in real interest rate reflect either abundant capital flows into debt that investors considered to be safe because it was issued in euros; or convergence in nominal returns across euro area member states. Either way, the story translated into private-sector debt accumulation. As Figure 8 shows, from 1999 to 2008, non-financial corporations increased their debt from 50 percent of GDP to 78 percent in Italy and to 113 percent in Spain. In France and Germany, where the drop of real interest rates was much smaller, the changes in non-financial corporate debt were much smaller. Debt increased only modestly in France and actually declined in Germany over this period.

Did the collapse in real interest rates in the periphery, and the run-up in non-financial corporate debt, lead to a worsening in the allocation of capital? Such an effect could arise through three non-exclusive channels. First, international macroeconomics has long pointed out 
the risk that capital inflows boost non-tradable output such as services or construction ${ }^{23}$, which tend to have lower productivity (and productivity growth) than manufacturing and other tradables. Recent evidence is provided by Kalantzis (2014) and Benigno et al. (2015). ${ }^{24}$

A second form includes misallocation of capital across firms within sectors following fast credit growth (Reis, 2013, and Gopinath et al. 2015). Gopinath et al. (2015) show that the marginal product of capital has become more dispersed in southern Europe, including within manufacturing. This is evidence that the firms with the highest productivity did not crowd out the least efficient firms. ${ }^{25}$

Third, Challe, Lopez and Mengus (2015) propose a model whereby easier financing conditions lead to “soft budget constraints.” In their model, lower interest rates raise the tolerance for weaker institutions such as rule of law. They show that more negative current accounts are correlated with a lower degree of rule of law, which weighs on economic growth. More broadly, institutional quality has declined in many southern euro-area economies since the mid-1990s.

All three mechanisms could apply to the southern euro area, which is where the effects on funding costs were most dramatic. Although the discussions are often in terms of capital flows, the mechanisms in the models generally focus on how interest-rate changes affect economic incentives. Clearly, interest rates and capital flows are related, but imperfectly. For this reason, we focus our empirical work on links between productivity growth and real interest rates.

\footnotetext{
${ }^{23}$ For instance, construction reached a very large fraction of Spanish GDP in the run up to the crisis, as foreign capital financed its nearly 10 percent current account deficit in the years around 2005.

${ }^{24}$ In’t Veld et al. (2014) and Kollman et al. (2015) consider the drivers and consequences of capital flows for Spain and Germany, respectively, in the context of estimated DSGE models. These papers consider the broader implications of euro-area convergence for macroeconomic outcomes, including analyzing different factors influencing the relationship between interest rates and net capital flows.

${ }^{25}$ On the effects of financial exuberance or credit booms on productivity see also Gorton and Ordonez (2015), Cechetti and Kharroubi (2015), and Borio et al. (2015).
} 
We first test this hypothesis through simple VARs that include the growth rate of labor productivity and the real interest rate. Given that the real interest rate should, in the long run, respond to the productivity growth rate, ${ }^{26}$ we focus on the effects of shocks to the real interest rate after allowing for past and contemporaneous innovations to productivity growth. In VAR language, we identify shocks with a Cholesky decomposition that orders the real interest rate last in our specification. That ordering constrains productivity growth to react to interest-rate shocks only with a lag. In contrast, real interest rates can respond immediately to productivity shocks.

Interest rates can, of course, change for a wide range of economic reasons-monetary policy, risk premia, technology shocks, business-cycle conditions that affect inflation, and so forth. For the mechanisms in the models discussed above, it is not clear that the reasons matter. The models focus on how changes in real interest rates, whatever the cause, affect the decisions of economic agents and, through that, the allocation of resources.

For this reason, we do not seek to identify why real interest rates change. Of course, the mechanism itself is of interest and the VAR might well be too simple. Nevertheless, more complicated VAR results are often fragile, and it is not clear why the misspecification of simple specifications should show up only in southern Europe.

Our first specification uses, at the country and overall euro-area level, labor productivity, defined as the year-over-year growth rate of GDP divided by total employment, and the real interest rate reported in Figure 7. The sample period is from 1985Q1 to 2015Q1 for the Euro area, France, Spain, and the U.S., and, due to limited availability of the data, from 1992Q1 to 2015Q1 in Italy and Germany.

Figure 9 and Figure 10 report the impulse responses and the historical decomposition of this bivariate VAR for the euro area economy taken as a whole. As shown in the upper-right

\footnotetext{
${ }^{26}$ See Laubach and Williams (2015) for a discussion of factors affecting the natural rate of interest.
} 
panel of Figure 9, a positive shock to real interest rates triggers a significant increase in the growth rate of productivity that peaks about two years after the shock. The top panel of Figure 10 shows the historical decomposition of labor productivity in the euro area based on the VAR. The dashed line shows the contribution of shocks to the interest rate. According to the VAR, the sharp fall in the real interest rate of the euro area, which was largely been driven by Italy and Spain, explains some of the downward trend in the growth rate of labor productivity between 1995 and 2007. In particular, the dashed line shows that the interest rate contribution was positive in the 1990s but turned negative in the 2000s. Note that, despite the low rates since 2007, the VAR does not attribute much of post-crisis movements in productivity to interest rates. The lower panel shows the historical decomposition for real interest rates. Most moves in interest rates reflect shocks to the interest rate; the feedback from productivity is small.

The positive impact of shocks to the real interest rate on labor productivity also shows up at the country level in Italy, France, Spain, and Germany. It holds for richer specifications of the VAR where we include either GDP or hours, in addition to productivity and real rates, among the endogenous variables in the VAR.

Figure 11 shows the historical decomposition of labor productivity growth when the bivariate VAR is run country-by-country. The dashed lines show that the contribution of this shock to the downward trend of labor productivity is striking in Italy and Spain from 1995 to 2007. The contribution in France goes the same direction but is small. Germany is quite different, in part because real interest rates changed much less over time than in the rest of the euro area.

Turning to the U.S., Figure 12 shows that the estimated effect of interest rates on productivity (the upper right impulse response) is significant but much smaller in magnitude. 
Figure 12 (dashed line, top panel) shows that the contribution of the real interest rate to declining growth in labor productivity starts only around 2000 and is generally quite modest.

We take this first layer of evidence as showing that, while there tends to be an effect of real interest rates on productivity, the effect appears relatively modest at an aggregate level for most countries. However, for Italy and Spain, where the real interest rates declines were large, the effect is quantitatively significant.

Our second specification uses annual data on either labor productivity growth or TFP growth, from Cette, Lopez and Mairesse (2014) at the industry level, ${ }^{27}$ along with the real interest rate. Data on both real interest rates and productivity are available for 13 OECD countries (see the list in Table 1). These industry specific productivity data are available from 1990 to 2007 for 18 sectors at the industry level. We put country-specific real interest rates on the right side of the regression.

As shown in Table 1, changes in real interest rates are correlated with changes of similar magnitude for both measures of productivity one year later. ${ }^{28}$ This significant effect holds across the 13 countries or if we focus only on the four largest euro-area countries or more narrowly on particular sectors. However, the effects of the real interest rate on productivity in services are somewhat less precisely estimated when we focus on the four largest euro-area countries.

The point estimate of the coefficient is 0.2 across all sectors and as high as 0.35 if we focus on manufacturing in the euro area. Hence, the 5 to 6 percentage point (pp) decline in real

${ }^{27}$ We opt for the Cette, Lopez and Mairesse (2014) database for industry level estimates because it is available for the largest cross-section of industries. In addition, the capital stock series used to estimate TFP are constructed through a permanent inventory model, which does not require any interest rate hypothesis. This approach limits the chances that regressing TFP on real interest rates could be biased due to a mechanical effect of the real interest rate on the TFP series.

${ }^{28}$ The estimates in Table 1 are based on regressions of the growth rate of productivity on two of its lags and two lags of the real interest rate (as shown in Figure 8) and a country-sector fixed effect. The table reports the "total effects of the real interest rate" on the growth rate of productivity, defined as the sum of the coefficients on the two lags of the real interest rate in the regressions. 
interest rates that took place in Italy and Spain between 1995 and 2005 could explain as much as 1.2 pp slower growth rate of TFP for all sectors in these countries and even a 2.0 pp slower growth in the productivity of the manufacturing sectors.

These estimates tend to support the misallocation hypothesis of Reis (2013) and Gopinath et al. (2015). Indeed, the effects of the decline in real interest rates are stronger in manufacturing than in services. Hence the deterioration in aggregate productivity does not appear to be simply the result of channeling more funds to "non-tradable” sectors such as construction. The stronger effects in manufacturing may also work against the soft-budget-constraint hypothesis of Challe et al. (2015) which, presumably, should apply similarly across sectors.

Altogether, both the time series VAR evidence and the panel data regression reject the hypothesis that changes in the long-term real interest rate have no impact on productivity. Thus, these estimates are consistent with the view that the large declines in funding costs reduced productivity growth. This channel has had the largest effect in Italy and Spain where, from the mid-1990s to the mid-2000s real interest rates declined the most.

\section{Discussion and conclusions}

In major advanced economies, productivity growth was slowing prior to the Great Recession. The United States saw an exceptional burst of technological change in the second half of the 1990s and early 2000s. But that exceptional pace ended prior to the Great Recession. Other countries didn’t keep up with that frontier after the mid-1990s, but fell away at varying rates. Our preferred stories for Europe highlight the interaction of shocks and institutions. One shock was the ICT revolution, where Europe generally struggled to keep up. A second was the convergence process associated with the euro, where interest rates fell sharply. Both required more flexibility in labor- and product-market institutions (and, potentially, in Southern Europe, 
required better-quality institutions such as rule of law and lower "financial frictions") than Europe displayed.

The most striking empirical cases are in southern Europe, where productivity collapsed relative to the frontier. Although these countries could have suffered a particular severe case of the European "problem," the question is why the worst cases were all in the periphery of the euro area. In this regard, we provide novel macroeconomic evidence in favor of the hypothesis that productivity growth was low in part because real interest rates were low. This finding is consistent with another set of shocks-and-institutions theories: low interest rates fueled capital inflows which, in turn, were not allocated efficiently. Rising misallocation therefore reduced productivity growth.

The results in this paper have implications for debates about post-crisis economic performance as well as current policy issues.

First, that the productivity slowdown predated the Great Recession suggests that this event is not the sole factor explaining weak post-recession productivity growth. There is some evidence that deep recessions (financially related or otherwise) may cast "long shadows” (Fatas, 2000)_permanently reducing the level of GDP compared with its pre-recession trend (e.g., Cerra and Saxena, 2008, Martin and Wilson, 2013, and Blanchard et al. 2015).

But there is much less evidence for advanced economies that the level or growth rate of TFP is permanently affected by recessions. For example, the Great Depression was an extraordinarily innovative period (Field, 2003; Alexopoulos and Cohen, 2009). More broadly, Oulton and Sebastiá-Barriel (2014) look at growth-accounting variables following financial crises. They find that, for developed countries, the long-run level of TFP is not significantly affected. According to their estimates, developed-economy GDP per capita is permanently lower 
after a financial crisis because employment per capita is permanently lower, whereas capital per worker as well as TFP are unchanged. ${ }^{29}$ Our results- that a lot was happening in terms of TFP trends before the crisis—are consistent with this literature. ${ }^{30}$

Second, even if there were hysteresis in TFP, the discussion of misallocation suggests a nuance in the interpretation of "aggregate technology.” Models such as Comin and Gertler (2006), in which technology has an important component that is endogenous to the cycle, typically consider a representative producer. But, as we saw, the mix of businesses can matter. Shocks may interact with country-specific institutions to affect the average productivity of the businesses that operate.

Third, the potential link between interest rates and TFP growth ties into concerns about secular stagnation. The recent period has seen “equilibrium” or "neutral” real rates at extraordinarily low levels around the world (e.g., Laubach and Williams, 2015). The link between interest rates and productivity growth suggests that, in countries with weak financial systems, a low-real-interest-rate environment could foster misallocation and impede productivity-enhancing reallocations. Thus, it may be that for some economies, the real rate that is consistent with static full employment is not consistent with maximum productivity growth.

Fourth, future productivity growth may depend importantly on supply-side reforms, such as liberalizing labor and product markets. Such reforms could affect both technological progress at the frontier as well as distance to the frontier.

${ }^{29}$ For developing economies, in contrast, financial crises do appear to permanently reduce TFP and capital per worker, as well as employment per capita. Furceri and Mourougane (2012) discuss GDP effects through hysteresis in labor markets or persistent effects on capital deepening if there are changes in risk premia. They also find that impact of financial crises varies according to structural features such as the degree of openness, macroeconomic imbalances, financial deepening, and the quality of governance.

${ }^{30}$ That said, without a formal model, we cannot say what would have happened to the path of global or country-level TFP in the absence of the Great Recession. Anzoategui et al. (2015) estimate a model where aggregate technology is endogenous to the cycle. According to their estimates, the Great Recession did, indeed, lower the path of TFP. For our purposes, the important point is that it's not the only factor. 
To see the role of reforms (and, relatedly, flexibility and dynamism) at the frontier, consider the following key drivers of future productivity growth: (i) ICT performance improvements, (ii) ICT diffusion, and (iii) the pace of complementary innovations (organizational and otherwise) throughout the broader economy. All three have mattered since the mid-1990s.

Techno-optimists tend to emphasize the possibilities of the first two—3D chips, artificial intelligence, soon-to-be pervasive robots, and the like. In terms of the third, Mokyr et al. (2015) point to gains in research efficiency and Fernald and Jones (2014) point to the increasingly global nature of innovation spending. Competitive pressures and structural rigidities may affect the incentives to improve ICT but are probably more important for diffusion and for complementary innovations and reorganizations. That the U.S. was able to implement broadbased ICT-related reorganization in the past does not make it easy or certain in the future.

In this regard, techno-pessimists often emphasize the challenges with the third driver: For ICT to have a broad-based effect, substantial organizational changes are likely to be needed. As we saw in the case of U.S. retailing, these changes may take place within existing businesses, or else in terms of new businesses being created and more productive ones expanding. Those organizational changes are inherently costly and slow, and a wide range of frictions can get in the way. For this reason, even at the frontier, dynamism is likely to be important.

Away from the frontier, flexibility and dynamism appear even more important. Europe provides a clear case in which structural rigidities have gotten in the way. Removing those impediments can foster the possible catch-up towards U.S. levels of ICT diffusion and promote business and industry reorganizations. 
In Southern Europe, where the divergence in productivity has been particularly sharp and resource misallocation has been rising, the biggest potential gains come from steps to reverse the sharp pace of this divergence. According to our econometric estimates, higher real interest rates (which, in the post-recession period have reflected lower inflation rates in those economies) could help reduce misallocation and boost productivity growth somewhat. But of course, in economies with very low neutral real rates and considerable resource slack, interest-rate increases come at a cost in terms of macroeconomic stability. For this reason, structural and institutional reforms_-while challenging to implement—could help mitigate that tradeoff. That is, they could allow a return to a relatively high productivity-growth convergence path without requiring real interest rates that are above the levels consistent with full employment.

In sum, an implication of the pre-Great-Recession slowdown in productivity in Europe is that big gains in productivity are possible if those economies can get back on the convergence path. That would likely require ambitious structural reforms in many European economies to reverse anticompetitive regulations on labor and product markets and to reduce the importance of financial frictions.

That said, structural reforms face substantial institutional and political difficulties. Moreover, limited or non-appropriate reform programs could even make things worse (see, for example, Fatas, 2015). So, renewing the convergence process is far from assured. 


\section{Data appendix}

Bureau of Labor Statistics multifactor productivity (MFP) data and industry capital data were downloaded from http://www.bls.gov/mfp/mprdload.htm (accessed August 9, 2015). The industry classification system is NAICS. (In the text, we refer to these data as TFP.)

Bubble sectors are finance, insurance, and real estate (NAICS 52, 53); construction (23); agriculture (11); mining (21); and petroleum refining (324). This is the same list as in Fernald (2014) with the addition of petroleum refining. ICT-producing industries are Computer and Electronic Products (NAICS 334), Information and Data Processing Services $(518,519)$ and Computer Systems Design and Related Services (5415).

We define market services in the BLS data as

- Wholesale and retail trade (NAICS 42, 44-45);

- Transportation $(48,49)$

- Information excluding publishing (51 excluding 511 and 516 (publishing)

- Business services-e.g., legal, professional, scientific, management administrative, excluding computer systems and design (NAICS 54-56, excluding 5415)

This listing of market services intentionally excludes the bubble sector of finance (which is usually considered a business service) as well as the ICT-producing information and computer services (software and computer systems integration) sector.

In terms of size, from 1995-2000, ICT production was 6 percent of business-sector value added; bubble sectors were 24 percent; and market services and the residual “other” category were both 35 percent.

EU KLEMS. Industry data were obtained from http://www.euklems.net/ (accessed September 12, 2015) for the ISIC Rev. 4 vintage. For major economies, the files have industry data through 2009 or 2010. The industries allow a reasonable correspondence with the groupings used with the BLS data and described above. (For the U.S., we chose to use the BLS rather than EU KLEMS data, because it was more recent. However, the conclusions in this paper do not appear affected by this choice.)

Times series used in the VAR: Labor productivity is four-quarter growth in GDP per employee. The long-term real interest rate is defined as the 10-year government interest rate minus the current four-quarter growth in the GDP deflator. The time series for GDP, GDP deflator, employment, and the 10-year government interest rate were downloaded from Datastream. 


\section{References}

Aghion, Philippe, Philippe Askenazy, Renaud Bourlès, Gilbert Cette and Nicolas Dromel (2009): "Education, Market Rigidities and Growth”, Economics Letters 102 (1), pp. 62-65.

Alexopoulos, Michelle and Jon Cohen (2009). "Measuring our Ignorance, One Book at a Time: New Indicators of Technological Change, 1909-1949.” Journal of Monetary Economics, Volume 56, Issue 4, May, Pages 450-470.

Andrews, Dan, Chiara Criscuolo, and Peter N. Gal (2015). "Frontier firms, technology diffusion and public policy: Micro evidence from OECD countries." Manuscript, OECD.

Anzoategui, Diego, Diego Comin, and Joseba Martinez (2015). "Endogenous Technology Adoption and R\&D as Sources of Business Cycle Persistence." Manuscript.

Barnett, A, S Batten, A Chiu, J Franklin, and M Sebastiá-Barriel (2014), "The UK productivity puzzle”, Bank of England Quarterly Bulletin, 2014 Q2, pp. 114-128.

Bartelsman, Eric, 2013. "ICT, Reallocation and Productivity," European Economy - Economic Papers 486, Directorate General Economic and Monetary Affairs (DG ECFIN), European Commission.

Bartel, Ann, Casey Ichniowski, and Kathryn Shaw (2007). "How Does Information Technology Affect Productivity? Plant-Level Comparisons of Product Innovation, Process Improvement, and Worker Skills.” Quarterly Journal of Economics, November: 17211758.

Bartelsman, Eric, John C. Haltiwanger, and Stefano Scarpetta. 2009. "Measuring and Analyzing Cross-Country Differences in Firm Dynamics.” In Producer Dynamics: New Evidence from Micro Data, edited by Timothy Dunne, J. Bradford Jensen, and Mark J. Roberts, 15-76. Chicago: University of Chicago Press.

Basu, Susanto and John G. Fernald (2002). “Aggregate Productivity and Aggregate Technology.” European Economic Review.

Basu, Susanto, John Fernald, Nicholas Oulton, and Sally Srinivasan (2003). "The Case of the Missing Productivity Growth: Or, Does Information Technology Explain Why Productivity Accelerated in the United States but Not the United Kingdom?” NBER Macroeconomics Annual, 2003.

Bellone, F., Mallen-Pisano, J. (2013), "Is misallocation higher in France than in the United States?”, Groupe de Recherche en Droit, Economie, Gestion (GRE-DEG CNRS), University of Nice-Sophia Antipolis, Working Paper No 2013-38.

Benigno, Gianluca, Converse, Nathan and Fornaro, Luca, (2015). "Large capital inflows, sectoral allocation, and economic performance," Journal of International Money and Finance, Elsevier, vol. 55(C), pages 60-87.

Blanchard, Olivier, Eugenio Cerutti, and Lawrence Summers (2015). "Inflation and Activity: Two Explorations and Their Monetary Policy Implications.” Institute for International Economics Working Paper WP 15-19. 
Bergeaud, Antonin, Gilbert Cette and Remy Lecat (2014). "Productivity trends from 1890 to 2012 in advanced countries." Working papers 475, Banque de France, forthcoming in The Review of Income and Wealth.

Borio, Claudio, Enisse Kharroubi, Christian Upper and Fabrizio Zampolli, (2016). "Labour reallocation and productivity dynamics: financial causes, real consequences," BIS Working Papers 534, Bank for International Settlements.

Bosworth, Barry P. and Jack E. Triplett (2006). "Is the 21st Century Productivity Expansion Still in Services? And What Should Be Done About It?” Manuscript, Brookings Institution

Bourlès, Renaud, Gilbert Cette (2007). "Trends in 'structural' productivity levels in the major industrialized countries ”, Economics Letters, 95, pp. 151-156.

Bourlès, Renaud, Gilbert Cette, Jimmy Lopez, Jacques Mairesse, Giuseppe Nicoletti (2013). “Do product market regulations in upstream sectors curb productivity growth? Panel data evidence for OECD countries.” Review of Economics and Statistics 95 (5), 1750-1768.

Brynjolfsson, Erik and Lorin Hitt (2000). "Beyond computation: Information technology, organizational transformation and business performance." Journal of Economic Perspectives 10:1, pp 23-48.

Brynjolfsson, Erik and Andrew McAfee, 2014. The Second Machine Age: Work Progress, and Prosperity in a Time of Brilliant Technologies. New York: W. W. Norton \& Company.

Byrne, David M., John G. Fernald and Marshall B. Reinsdorf (2016). "Does the United States have a productivity slowdown or a measurement problem?” Conference paper prepared for Brookings Papers on Economic Activity, March.

Byrne, David M., Stephen D. Oliner, and Daniel E. Sichel (2013). "Is the Information Technology Revolution Over?” International Productivity Monitor, vol. 25, pages 20-36, Spring.

Calligaris, Sara (2015). "Misallocation and Total Factor Productivity in Italy: Evidence from Firm-Level Data." CEIS Working Paper No. 357.

Cecchetti, Stephen and E. Kharroubi (2015). "Reassessing the impact of finance on growth", in proceedings of the Second International Research Conference of the Reserve Bank of India, forthcoming.

Cerra, V. and Saxena, S. (2008), "Growth dynamics: The myth of economic recovery," American Economic Review, Vol. 98(1), pp. 439-457.

Cette, Gilbert, Christian Clerc and Lea Bresson (2015). "Contribution of ICT diffusion to labour productivity growth: The United States, Canada, the Eurozone and the United Kingdom, 1970-2013”, International Productivity Monitor, N 28, Spring, pp. 81-88.

Cette, Gilbert and Jimmy Lopez (2012). "ICT demand behaviour: an international comparison.” Economics of Innovation and New Technology, 21, pp. 397-410.

Cette, Gilbert, Jimmy Lopez, and Jacques Mairesse (2013). "Upstream product market regulations, ICT, R\&D and productivity," Working papers 441, Banque de France, forthcoming in The Review of Income and Wealth. 
Cette, Gilbert, Jimmy Lopez, and Jacques Mairesse (2014). "Product and labor market regulations, production prices, wages and productivity", NBER, Working Paper Series, $\mathrm{n}^{\circ}$ 20563, October 2014.

Challe, Edouard, Jose Ignacio Lopez and Eric Mengus (2015): “The South of Europe’s Institutional Decline”, mimeo, Ecole Polytechnique.

Colecchia, A. and Paul Schreyer (2001), "ICT Investment and Economic Growth in the 1990s: Is the United States a Unique Case? A Comparative Study of Nine OECD Countries," OECD Science, Technology and Industry Working Papers, 2001/7, OECD Publishing.

Comin, Diego and Mark Gertler, 2006. “Medium-Term Business Cycles.” American Economic Review, vol. 96(3), pages 523-551, June.

Cowen, Tyler (2011). “The Great Stagnation: How America Ate All The Low-Hanging Fruit of Modern History, Got Sick, and Will (Eventually) Feel Better.” Penguin Group U.S., 2011.

Crafts, Nicholas and Kevin O’Rourke (2013) “Twentieth Century Growth”, Discussion Paper Series, CEPR, n 9633, September.

Doms, Mark (2004). "Productivity growth and the retail sector." FRBSF Economic Letter, Federal Reserve Bank of San Francisco, issue 17.

Fatas, Antonio (2000). "Do business cycles cast long shadows? Short-run persistence and economic growth.” Journal of Economic Growth, Vol 5, issue 2, 147-162.

Fatas, Antonio (2015). "The agenda for structural reform in Europe.” Forthcoming in Growth and Reform: European Economies in the Wake of the Economic Crisis, Oxford University Press.

Fernald, John (2014). "Productivity and Potential Output Before, During, and After the Great Recession.” NBER Macroeconomics Annual 2014.

Fernald, John and Charles Jones (2014). “The Future of U.S. Economic Growth.” AEA Papers and Proceedings, May 2014.

Fernald, John and Brent Neiman (2011). "'Growth Accounting with Misallocation: Or, Doing Less with More in Singapore," American Economic Journal: Macroeconomics, American Economic Association, vol. 3(2), pages 29-74, April.

Fernald, John and Shanthi Ramnath (2003). "Information Technology and the U.S. Productivity Acceleration.” Chicago Fed Letter, No. 193, September.Fernald, John and Bing Wang, 2015. "The Rise and Fall of Exceptional Productivity Growth.” FRBSF Economic Letter.

Field, Alexander J. (2003). "The Most Technologically Progressive Decade of the Century." American Economic Review, 93(4): 1399-1413.

Furceri, Davide and Annabelle Mourougane (2012): “The effect of Financial Crises on Potential Output: New Empirical Evidence from OECD Countries, Journal of Macroeconomics, 34, pp. 822-832.

Foster, Lucia, John C. Haltiwanger, and Cornell J. Krizan (2006). "Market Selection, Reallocation, and Restructuring in the U.S. Retail Trade Sector in the 1990s," The Review of Economics and Statistics, vol. 88(4), pages 748-758, November. 
Garcia-Santana, M., E. Moral-Benito, J. Pijoan-Mas, and R. Ramos (2015). Growing like Spain: 1995-2007," Tech. rep.

Garicano, Luis, Claire Lelarge, and John Van Reenen (2012). "Firm Size Distortions and the Productivity Distribution: Evidence from France.” Manuscript.

Haskel, Jonathan, Peter Goodridge, and Gavin Wallis (2015). "Accounting for the UK productivity puzzle: a decomposition and predictions," Working Papers 21167, Imperial College, London, Imperial College Business School.

Gopinath, Gita, Sebnem Kalemli-Ozcan, Loukas Karabarbounis, and Carolina Villegas-Sanchez (2015). “Capital Allocation and Productivity in South Europe.” NBER Working Paper No. 21453.

Gordon, Robert J. (2014). “The Demise of U.S. Economic Growth: Restatement, Rebuttal, and Reflections.” NBER WP 19895, February.

Gorton, Gary and Guillermo Ordonez (2015). “Good Booms, Bad Booms.” Manuscript, University of Pennsylvania.

Greenwood, Jeremy and Mehmet Yorukoglu (1997). "1974," Carnegie-Rochester Conference Series on Public Policy, Elsevier, vol. 46(1), pages 49-95, June.

Guerrieri, Paolo, Matteo Luciani, and Valentina Meliciani (2011): "The determinants of investment in information and communication technologies." Economics of Innovation and New Technology 20 (4), pp. 387-403.

Haltiwanger, John, Stefano Scarpetta, Helena Schweiger (2014). “Cross country differences in job reallocation: The role of industry, firm size and regulations.” Labour Economics, Vol 26 (January), pages 11-25. doi:10.1016/j.labeco.2013.10.001.

Hsieh, Chang-Tai and Peter Klenow (2009). "Misallocation and Manufacturing TFP in China and India." Quarterly Journal of Economics 124, November, 1403-1448.

IMF 2015. "Uneven Growth: Short- and long-term factors.” World Economic Outlook, April 2015.

in’t Veld, Jan, Robert Kollmann, Beatrice Petaracchia, and Werner Roeger, 2014. International Capital Flows and the Boom-Bust Cycle in Spain. Journal of International Money and Finance 48, 314-335.

Inklaar, Robert (2015). “The Industry Sources of Productivity Growth and Convergence.” Manuscript, Groningen Growth and Development Centre.

Inklaar, Robert and Marcel P. Timmer (2008). "Accounting for growth in retail trade: an international productivity comparison.” Journal of Productivity Analysis, 29:23-31.

Inklaar, Robert and D.S. Prasada Rao (2014). "Cross-country income levels over time: did the developing world suddenly become much richer?” GGDC Research Memorandum 151.

Jorgenson, Dale W., Mun S. Ho, and Kevin J. Stiroh (2008). "A Retrospective Look at the U.S. Productivity Growth Resurgence." Journal of Economic Perspectives, 22(1): 3-24.

Kalantzis, Yannick (2014). "Financial fragility in small open economies: firm balance sheets and the sectoral structure," Working papers 505, Banque de France, forthcoming in the Review of Economic Studies. 
Kollmann, Robert, Marco Ratto, Werner Roeger, Jan in’t Veld and Lukas Vogel, 2015. What Drives the German Current Account? And How Does it Affect Other EU Member States? Economic Policy, January 2015, pp.47-93.

Laubach, Thomas and John C. Williams (2015). "Measuring the Natural Rate of Interest Redux.” Federal Reserve Bank of San Francisco Working Paper 2015-16. http://www.frbsf.org/economic-research/publications/working-papers/wp2015-16.pdf.

Martin and Wilson (2013), "Potential output and recessions: Are we fooling ourselves?” manuscript.

Mokyr, Joel, Chris Vickers and Nicolas L. Ziebarth (2015): “The history of technological anxiety and the future of economic growth: Is this time different?”, Journal of Economic Perspective, Vol. 29, N³, Summer, pp. 31-50.

OECD (2015). “The Future of Productivity.” Organization of Economic Cooperation and Development, Paris.

Oulton, Nicholas and María Sebastiá-Barriel (2013). “Effects of Financial Crises on Productivity, Capital and Employment. Paper Prepared for the IARIW-UNSW Conference on "Productivity: Measurement, Drivers and Trends." Sydney, Australia, November 26-27, 2013.

Pellegrino, Bruno and Luigi Zingales (2014). “Diagnosing the Italian Disease.” Manuscript.

Pilat, Dirk and Frank C. Lee (2001). "Productivity Growth in ICT-producing and ICT-using Industries: A Source of Growth Differentials in the OECD?" OECD Science, Technology and Industry Working Papers 2001/4, OECD Publishing.

Reis, Ricardo (2013). “The Portuguese Slump and Crash and the Euro Crisis.” Brookings Papers on Economic Activity, 46, 143-193, Spring.

Schreyer, Paul (2000). "The Contribution of Information and Communication Technology to Output Growth: A Study of the G7 Countries.” OECD Science, Technology and Industry Working Papers 2000/2, OECD Publishing.

Stiroh, Kevin (2008). "Information Technology and Productivity: Old Answers and New Questions," CESifo Economic Studies, CESifo, vol. 54(3), pages 358-385, September.

Tett, Gillian (2015). “Productivity paradox deepens Fed's rate-rise dilemma.” Financial Times, August 20, 2015. http://www.ft.com/intl/cms/s/0/159496e4-4739-11e5-b3b21672f710807b.html\#axzz3lgxteSJ3.

Marcel P. Timmer \& Robert Inklaar \& Mary O'Mahony \& Bart van Ark, 2011. "Productivity and Economic Growth in Europe: A Comparative Industry Perspective," International Productivity Monitor, Centre for the Study of Living Standards, vol. 21, pages 3-23, Spring.

Van Reenen, John, Nicholas Bloom, Mirko Draca, Tobias Kretschmer, Raffaella Sadun, Henry Overman, and Mark Schankerman, 2010. “The Economic Impact of ICT.” Research report, SMART N. 2007/0020. 
van Ark, Bart, Mary O’Mahony, and Marcel P. Timmer (2008). The Productivity Gap between Europe and the United States: Trends and Causes. Journal of Economic PerspectivesVolume 22, Number 1 (Winter), pp. 25-44. 
Table 1: Effects of real interest rates on productivity

Total effect of the real interest rate on the growth rate of productivity (18 sectors for 13 countries)

\begin{tabular}{|c|c|c|c|c|c|c|c|c|}
\hline & \multicolumn{4}{|c|}{ TFP. 1995-2008 } & \multicolumn{4}{|c|}{ Labor productivity. 1995-2008 } \\
\hline & \# obs & Coef. & St Dev & T. Stat & \# obs & Coef. & St Dev & T. Stat \\
\hline \multicolumn{9}{|l|}{13 countries } \\
\hline All sectors & 2932 & 0.20 & 0.07 & 2.70 & 3055 & 0.19 & 0.068 & 2.86 \\
\hline Manufacturing & 1992 & 0.20 & 0.09 & 2.17 & 2072 & 0.17 & 0.085 & 2.01 \\
\hline Services & 595 & 0.23 & 0.09 & 2.55 & 635 & 0.25 & 0.08 & 3.10 \\
\hline \multicolumn{9}{|c|}{ Euro area 4 (Germany. France. Italy. Spain) } \\
\hline All sectors & 1196 & 0.16 & 0.09 & 1.90 & 976 & 0.27 & 0.096 & 2.80 \\
\hline Manufacturing & 659 & 0.35 & 0.11 & 3.15 & 659 & 0.39 & 0.11 & 3.59 \\
\hline Services & 201 & 0.18 & 0.10 & 1.67 & 205 & 0.19 & 0.11 & 1.71 \\
\hline
\end{tabular}

Manufacturing: Food; Textiles; Wood Pulp and Paper, Chemicals, Other non metal., Basic metal., Machinery equipment, Electric and optical equip., Utilities.

Services: Trade, Hotels\&Restaurants, Transport, Renting

All sectors includes manufacturing, services, construction, and financial intermediation

Countries are the euro-area 4 and the U.S., Japan, UK, Canada, Austria, Denmark, Finland, the Netherlands, and Sweden.

Coefficients in bold if t-stat is greater than 2. 
Figure 1: TFP convergence and divergence in Advanced Economies

\section{TFP level relative to the United States}

ppp US\$2010 - US = 100

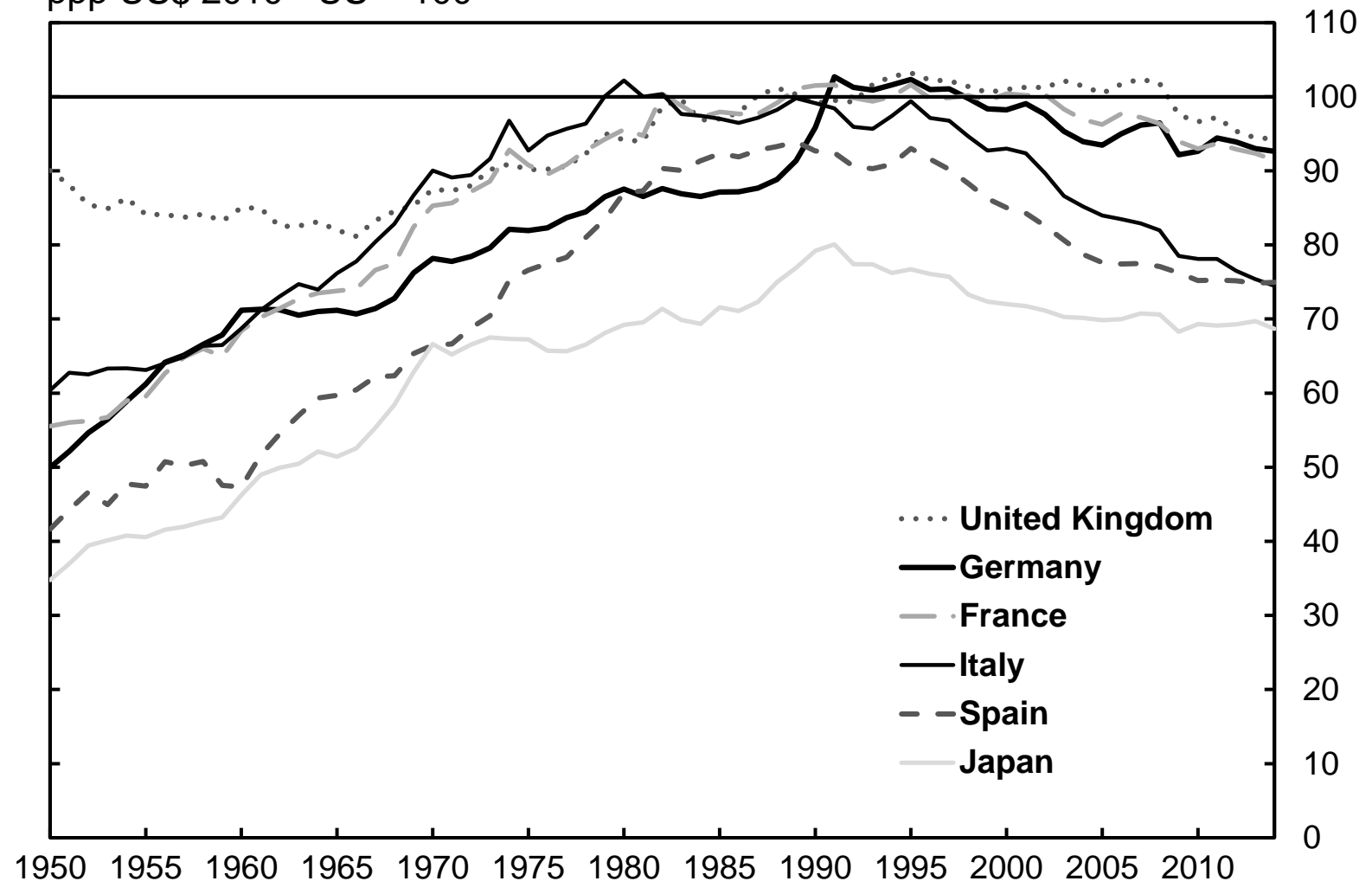

Source: Bergeaud, Cette and Lecat (2014). 
Figure 2: Labor productivity convergence and divergence

\section{GDP per hour worked relative to the United States}

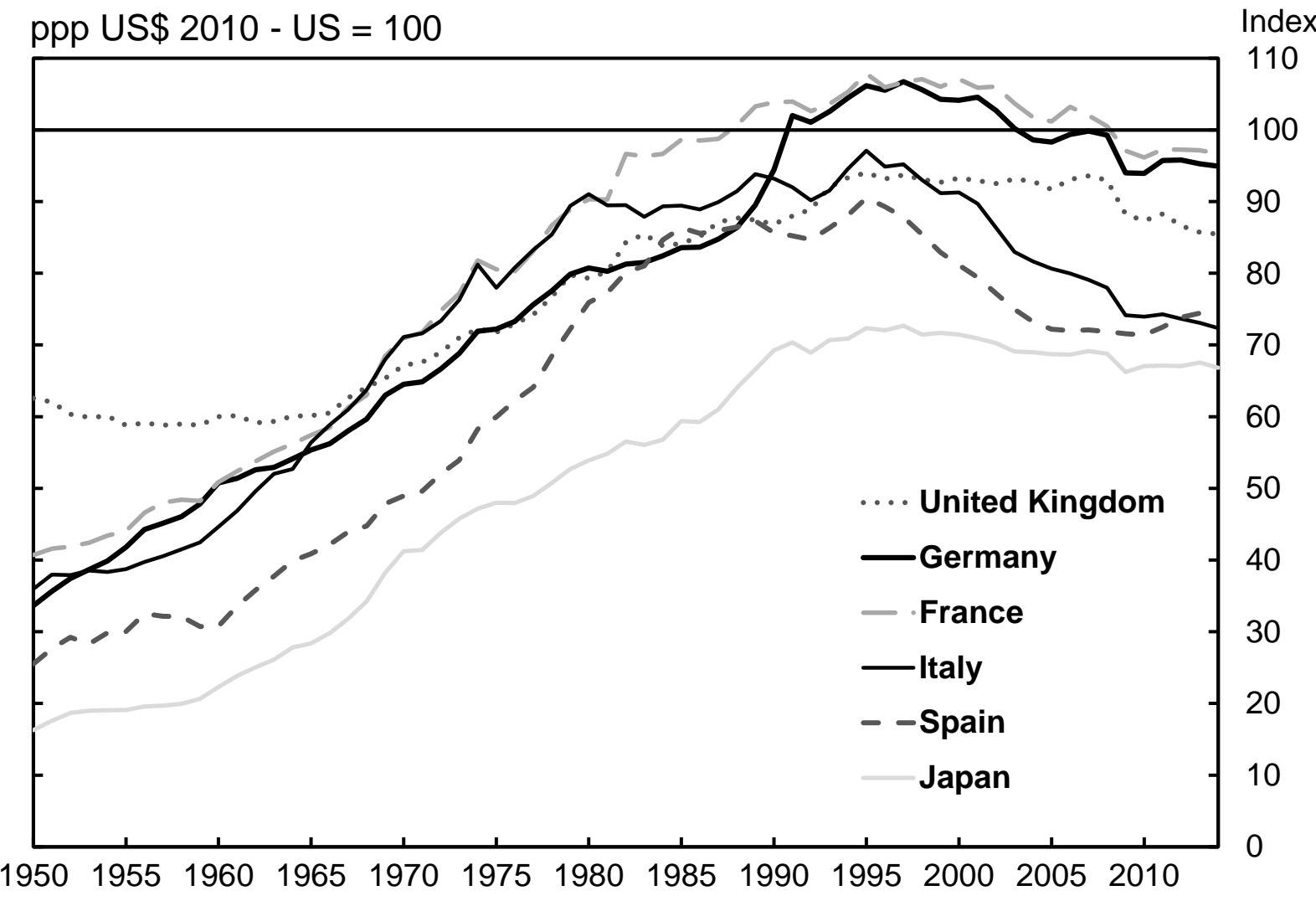

Source: Bergeaud, Cette and Lecat (2014). 
Figure 3: Labor productivity growth accounting

\section{Decomposing growth in GDP per hour}

Bars sum to growth GDP per hour growth, annual rate

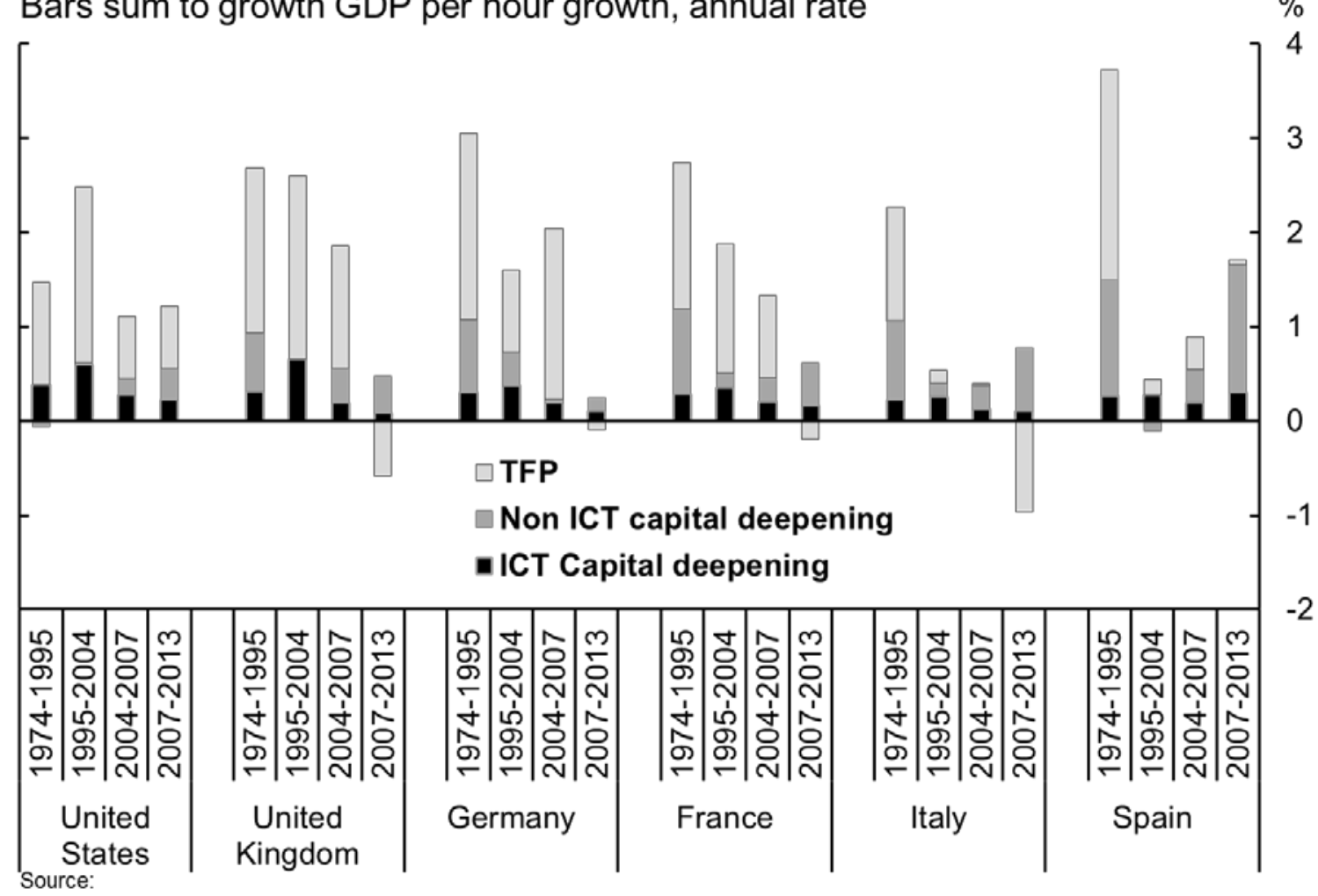

Source: Bergeaud, Cette, and Lecat (2014) and Cette, Clerc and Bresson (2015). 
Figure 4: Contribution to U.S. TFP growth by industry subgroup

\section{Business-sector TFP growth, United States}

Contribution by industry subgroup, annual percentage points Percentage points

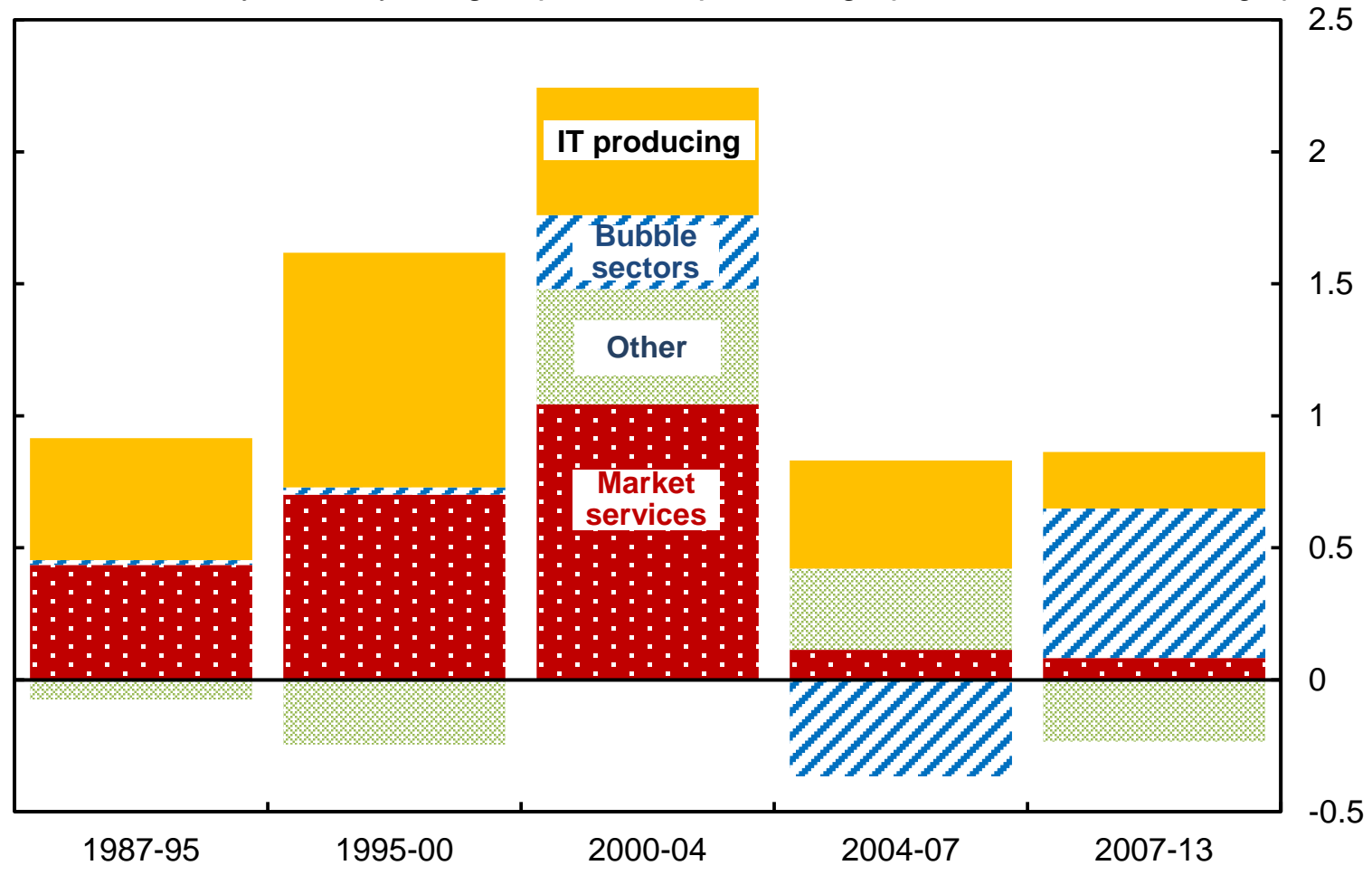

Notes: Business-sector TFP growth from BLS industry data is decomposed into four mutually exclusive categories. "IT producing" is computers/electronic products, publishing, and computer systems integration. "Bubble sectors" are construction, finance, real estate, agriculture, mining, and petroleum refining. "Market services" are wholesale and retail trade, transportation, information (except publishing, which includes software), and business services. "Other" is the residual, and is manufacturing (excluding petroleum refining and computers/electronic products), utilities, and services not included elsewhere. Source: BEA, BLS, Fernald (2014), and authors' calculations. 
Figure 5 Contribution to European TFP growth by industry subgroup

TFP growth, Germany

Contribution by industry subgroup, annual percentage points

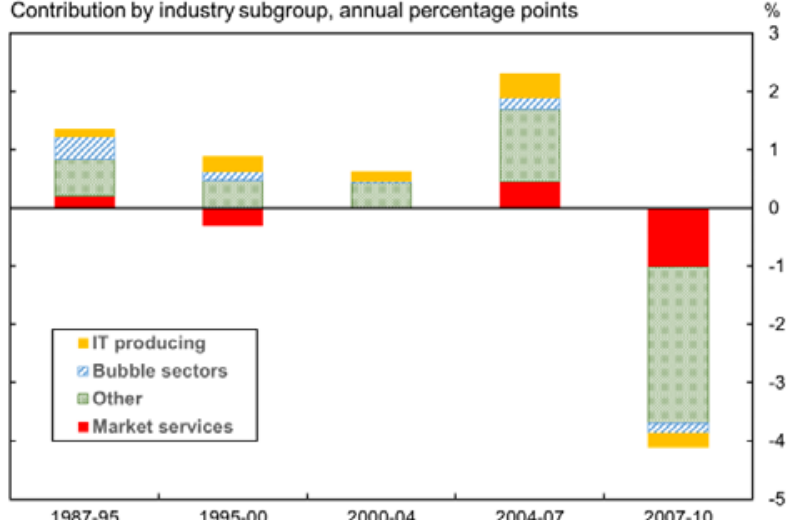

$1987-95$

1995-00

TFP growth, Italy

Contribution by industry subgroup, annual percentage points

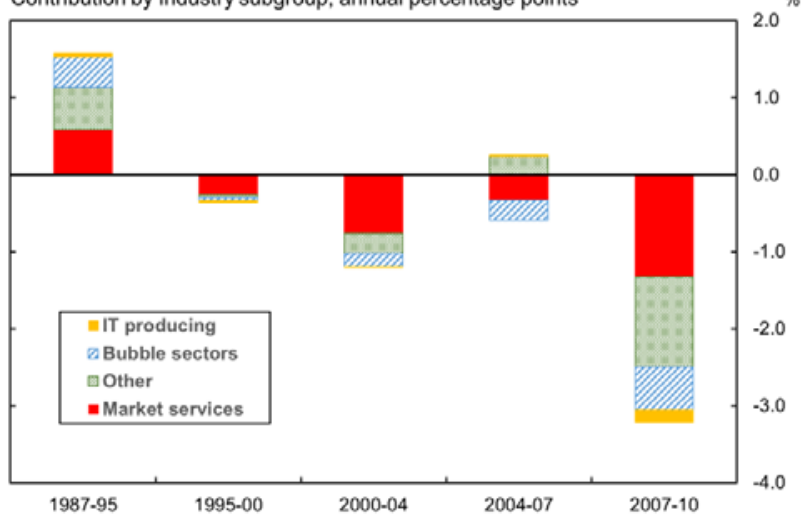

TFP growth, France

Contribution by industry subgroup, annual percentage points

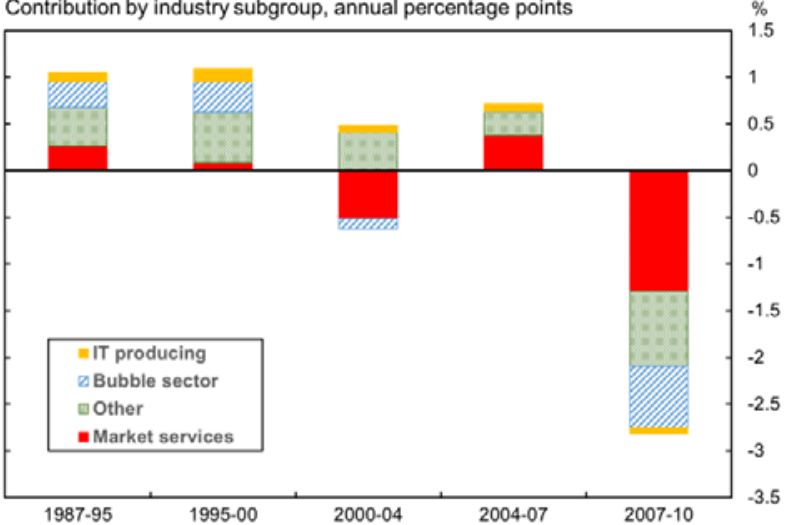

TFP growth, Spain

Contribution by industry subgroup, annual percentage points

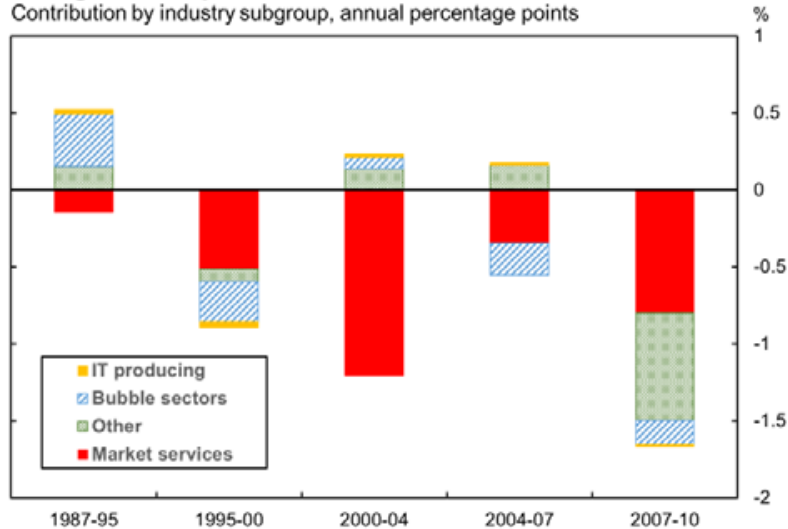

Notes: Industry categories correspond to those shown in Figure 4. See notes to that figure. Source: EU KLEMS and authors' calculations. 
Figure 6: Nominal interest rates in Europe

\section{Nominal interest rates}

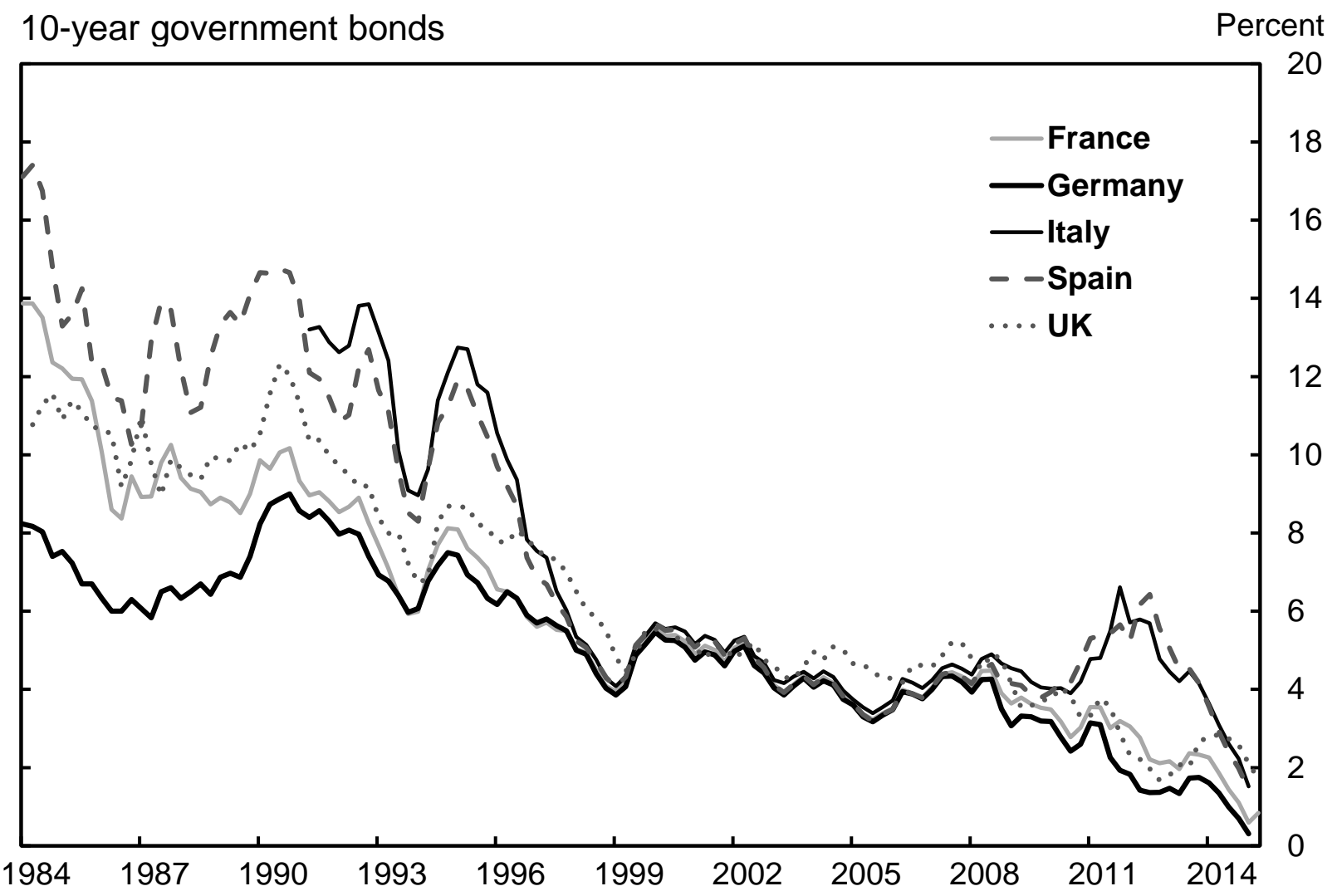

Source: Datastream. 
Figure 7: Real interest rates in Europe

\section{Real interest rates}

10-year gov. bond rate less 4-quarter percent change in GDP deflator Percent

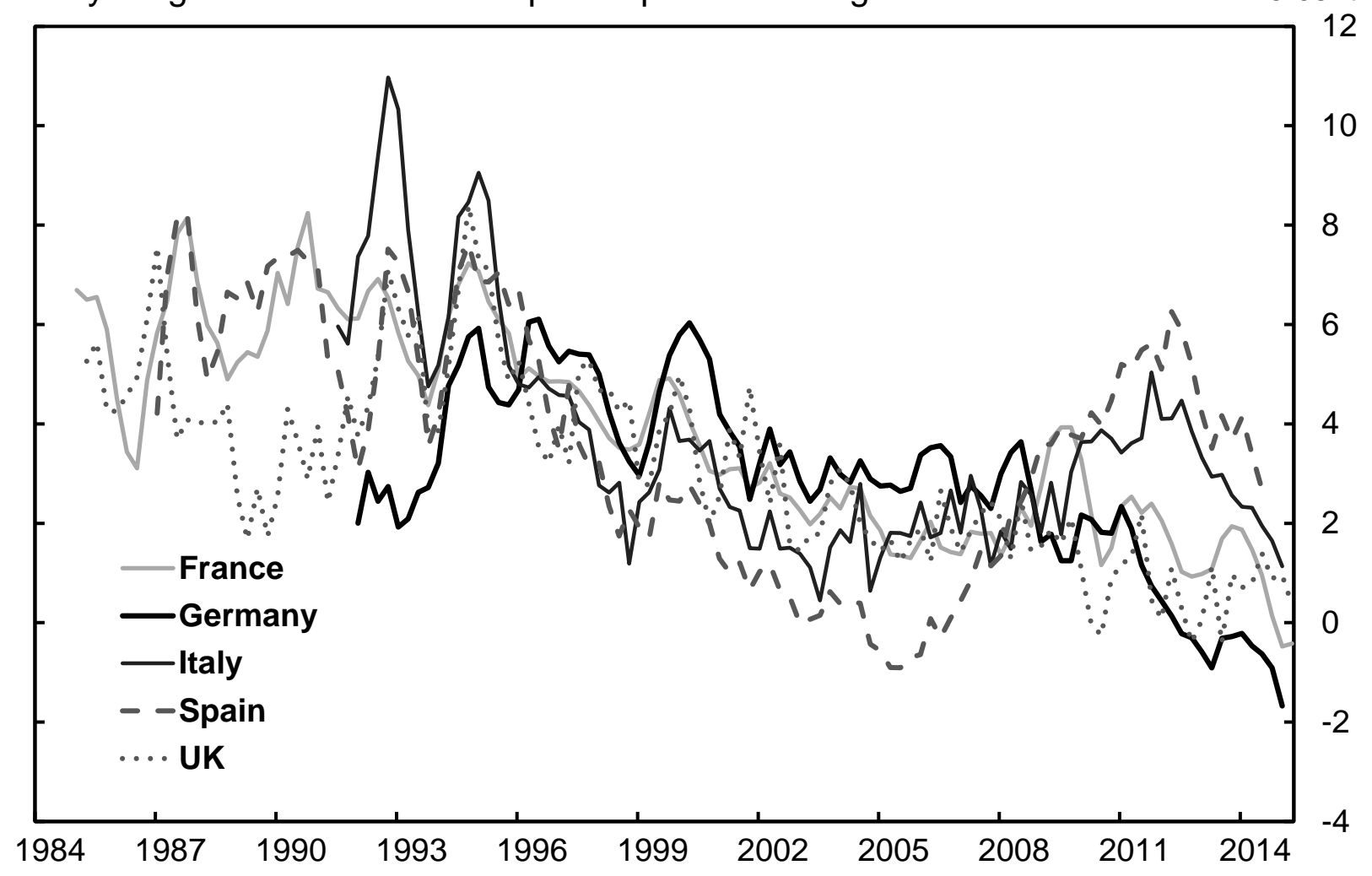

Source: Datastream. 
Figure 8: Non-financial corporate debt in Europe and the U.S.

\section{Non-financial corporate debt}

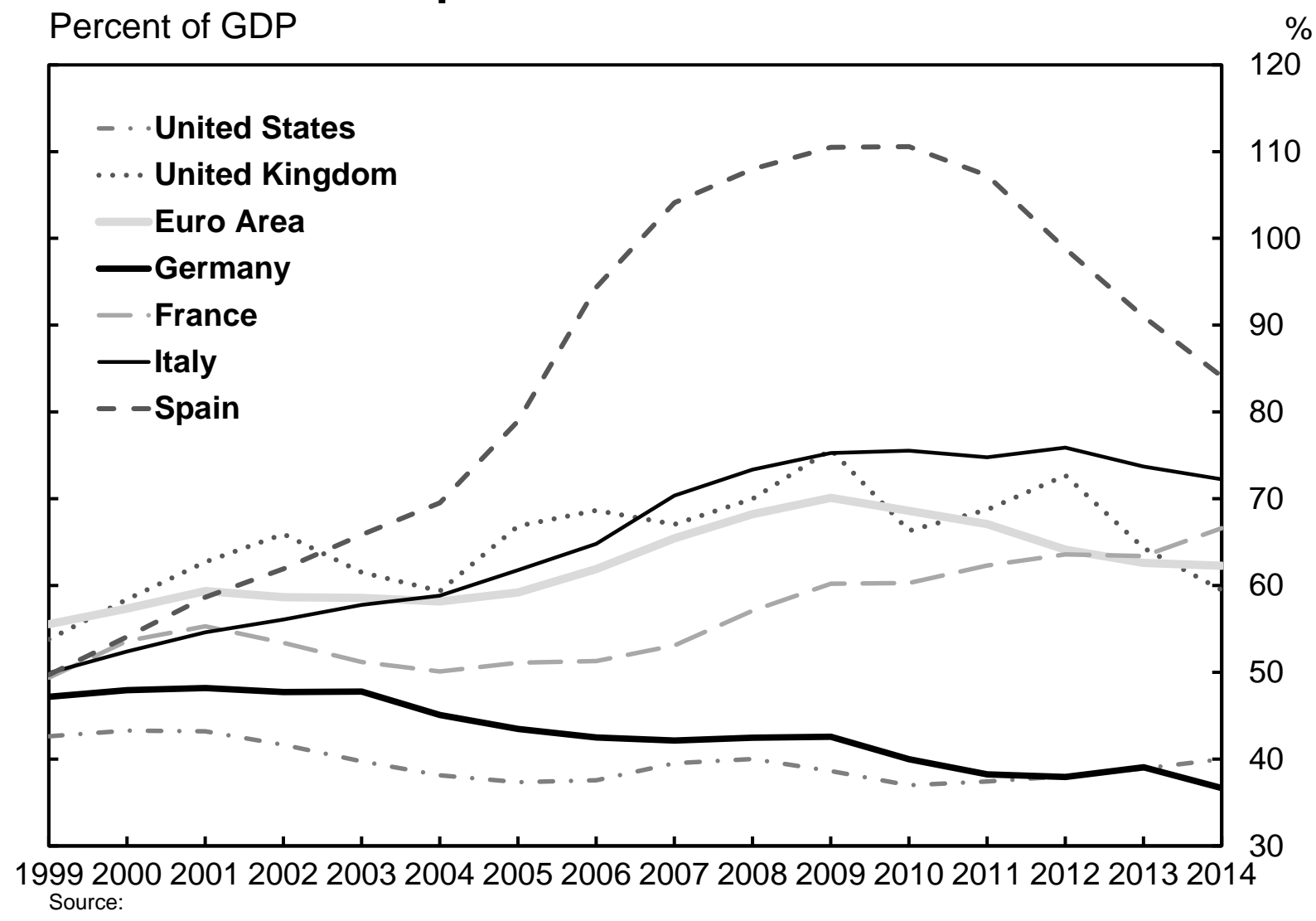

Source: Banque de France. 
Figure 9: Euro-area VAR evidence on effects of real interest rates on labor productivity
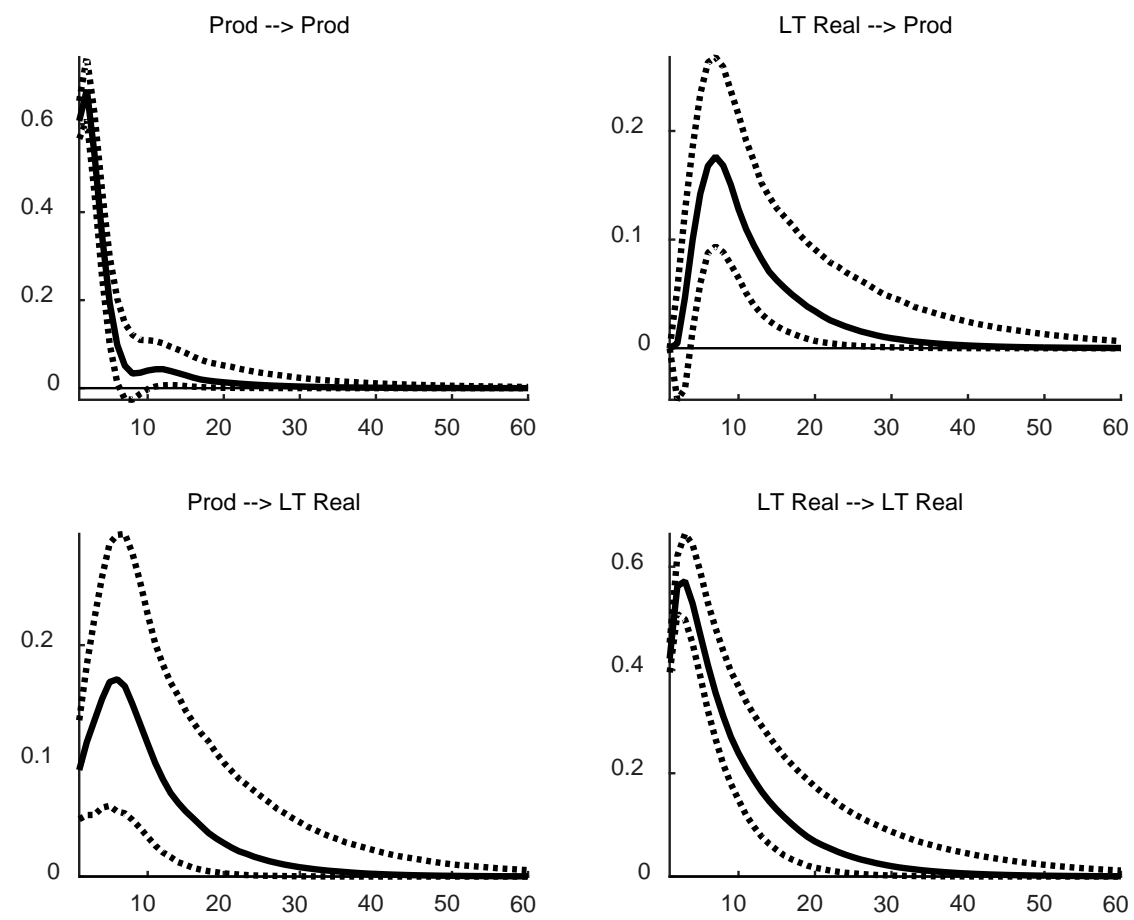

Notes: Impulse response functions (and 10\% and 90\% confidence bounds) from a bivariate VAR of the euro-area year-over-year growth rate of labor productivity and the long-term real interest rate; estimation with two quarterly lags from 1985Q3 to 2015Q4. Shocks are identified with a Cholesky decomposition with the long-term interest rate placed second in the VAR. 
Figure 10: Historical VAR decomposition of Euro Area labor productivity
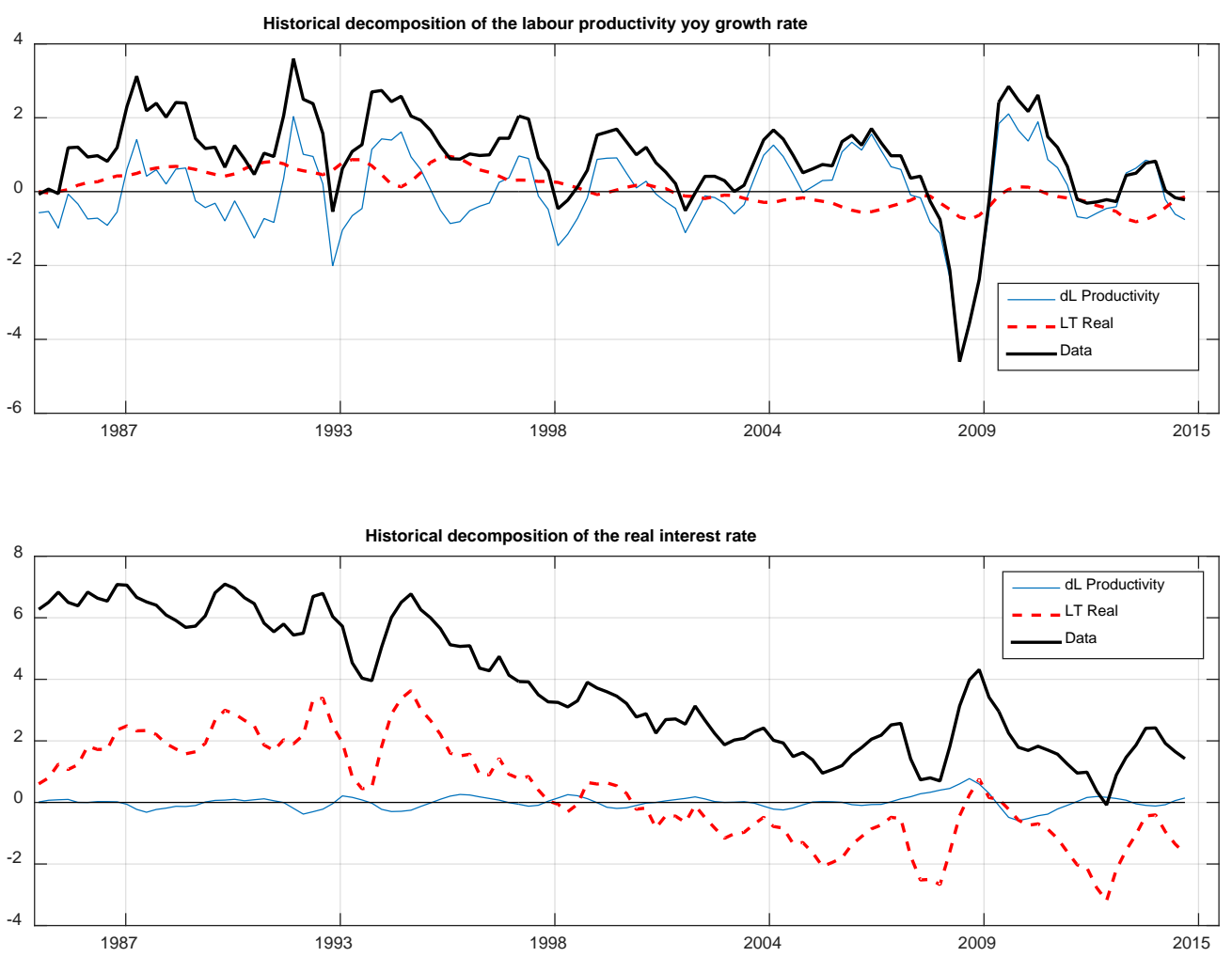

Notes: Historical decomposition from bivariate VAR. See notes to Figure 9. The thick solid line shows the data (labor productivity growth in top panel, real interest rate in the bottom panel). The thin solid line shows the contribution of shocks to labor productivity growth, the dashed line shows the contribution of shocks to the real interest rate. The data line is the sum of the two "shock" lines plus a constant term. 
Figure 11: Historical VAR decomposition of Euro Area labor productivity
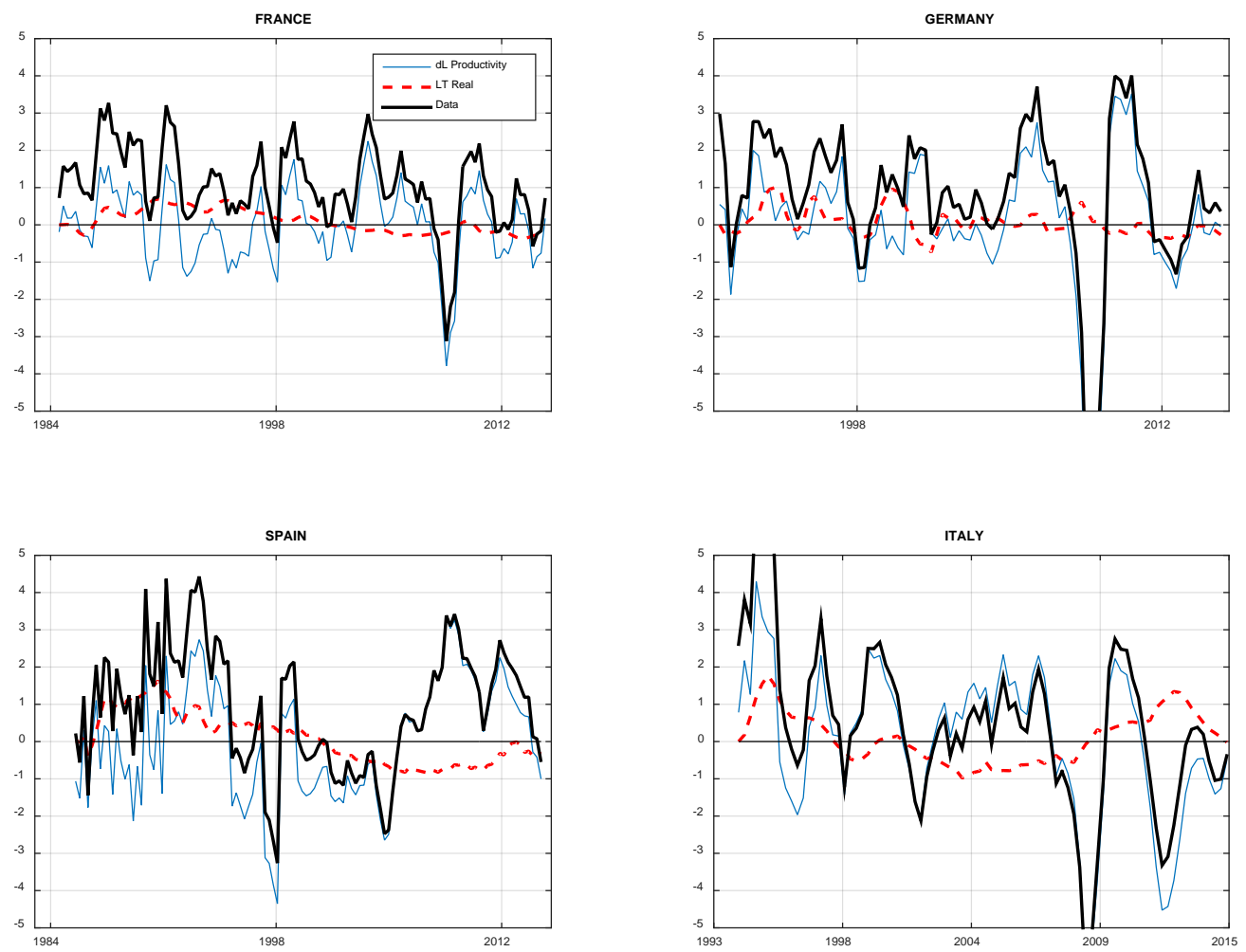

Notes: Historical decomposition from bivariate VAR similar to the one of the euro area (see note to figure 9) estimated at the country level. See also notes to Figure 10. 
Figure 12: U.S. VAR evidence on effects of real interest rates on labor productivity
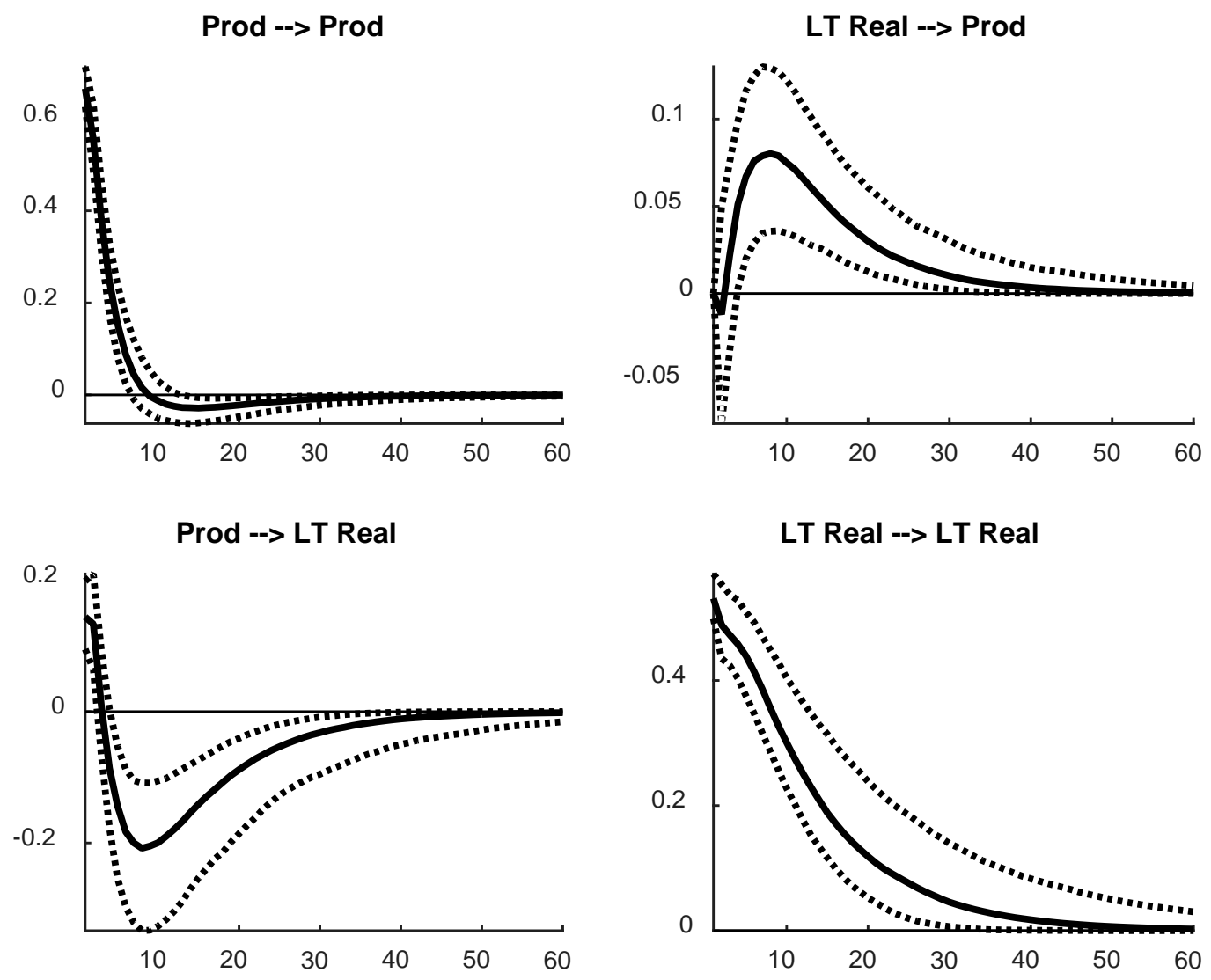

Notes: Impulse response functions (and 10\% and 90\% confidence bounds) from a bivariate VAR of the US year-over-year growth rate of labor productivity and the long-term real interest rate; estimation with two quarterly lags from 1985Q3 to 2015Q4. Shocks are identified with a Cholesky decomposition with the long-term interest rate placed second in the VAR. 
Figure 13: Historical VAR decomposition of U.S. labor productivity
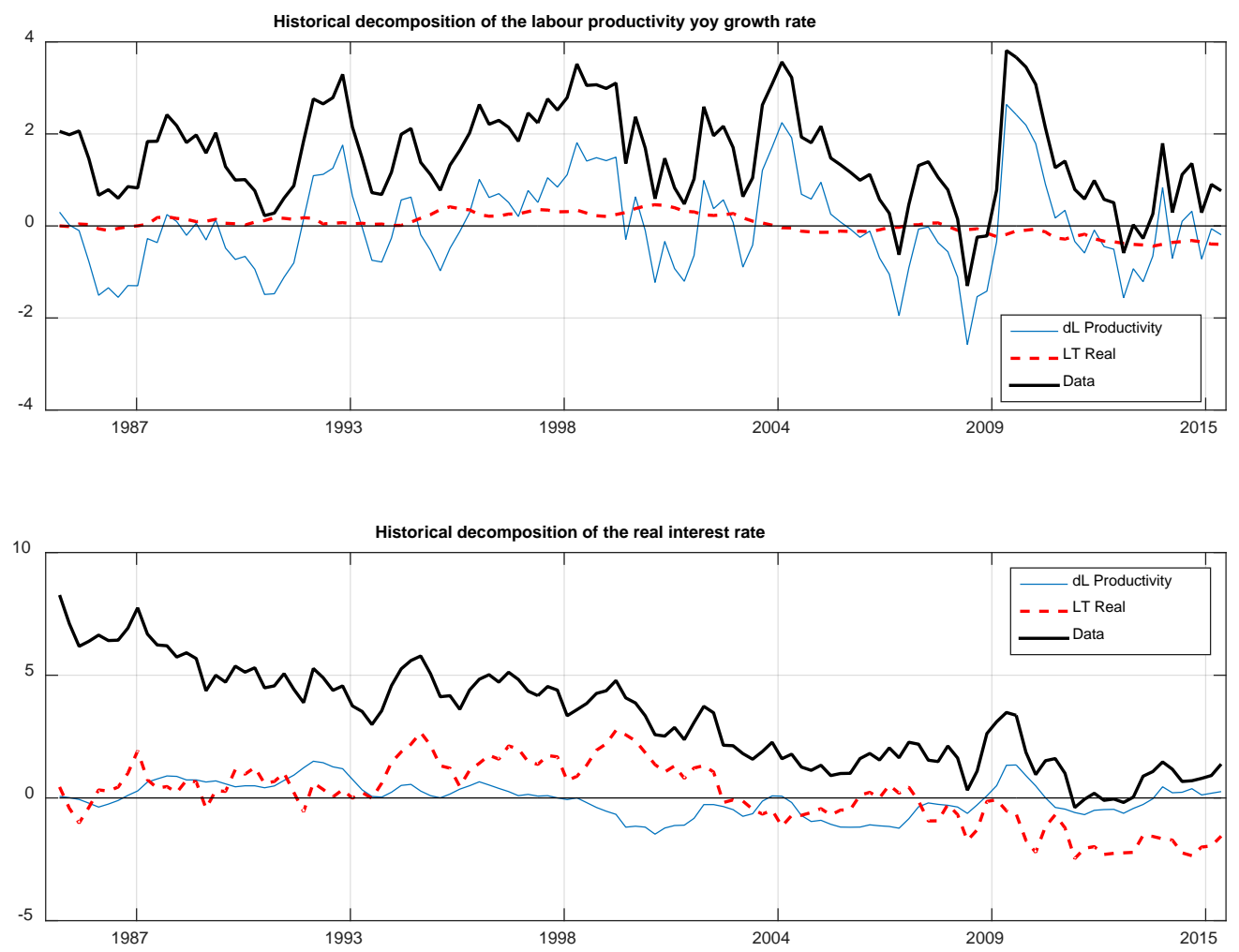

Notes: Historical decomposition from bivariate VAR. See notes to Figure 12 on the VAR and to Figure 10 regarding the historical decomposition. 